\title{
LA PATRAÑA DEL HOMBRE PREÑADO: ALGUNAS VERSIONES HISPÁNICAS
}

Figura harto conocida de los carnavales europeos es la del hombre disfrazado de mujer embarazada ${ }^{1}$. Con o sin parto simulado, la aparición de dicho personaje entra de lleno en la "imagen grotesca del cuerpo" y en el vitalismo cómico-fisiológico que M. Bajtín rastrea en la obra de Rabelais y en determinados aspectos de lo que llama "la cultura popular de la Edad Media y del Renacimiento"'. No cabe duda de que el hombre preñado bien puede pasar por la encarnación misma del espíritu festivo del carnaval, ya que sintetiza, en tono de broma, la función genética y el mecanismo de inversión transgresiva que antropólogos y folkloristas suelen considerar elemento esencial en las fiestas de este tipo ${ }^{3}$.

1 "Chaque sortie de masques a son homme enceint et sa famille des maies poussant un gros bebé. Leur comportement est partout des plus libres, des plus transgressifs", D. FABre y C. CAMBEROQUE, La fête en Languedoc. Regards sur le carnaval aujourd'hui, Toulouse, 1977, p. 165. También insisten sobre el tema C. Gaignebet y M. C. Florentin en Le carnaval, Payot, Paris, 1974, p. 148 (tipo de "vieja" embarazada).

${ }^{2}$ Sobre juegos y representaciones de esta índole en los carnavales del siglo XVI, S. Kinser promete un estudio en un libro de próxima aparición, The Birth of Gargantua. (Véase M. Grinberg y S. Kinser, "Les combats de carnaval et de carème", $A E S C, 38,1983$, p. 84). Mikhail Bakhtine, L'ouvre de François Rabelais et la culture populaire au moyen áge et sous la Renaissance, trad., par A. Robel, Gallimard, Paris, 1970, no menciona explícitamente el tema del hombre encinta, pero define el contexto mental en el que pudo elaborarse (caps. 5 y 6): nótese que inicia su estudio de la "imagen grotesca del cuerpo" con el análisis de una escena de la Commedia dell'arte que representa el parto simulado de una palabra por un tartamudo (pp. 302-308).

${ }^{3}$ Cf. Julio Caro Baroja, El carnaval (análisis histórico-cultural), Taurus, Madrid, 1965, passim. 
No obstante, es muy probable que esta representación tenga raíces antiguas y profundas, y que no se limite al contexto lúdico de las manifestaciones carnavalescas: parece que se relaciona en particular con el tema, más general, de la "locura", y que se halla asociado frecuentemente a la figura del "loco" o, por lo menos, a algunas especificaciones postmedievales de tan complejo e indeterminado personaje.

El loco tradicional, bien sea como bufón profesional, entidad patológica o incluso bobo de entremés (más de una vez, las fronteras entre dichas figuras resultan borrosas y desafían nuestro afán de imponer categorías y clasificaciones: pese a ser distintas por sus funciones y medios ambientales, no es infrecuente que intercambien sus atributos y características), presenta a menudo aspectos marcadamente fálicos, patentizados por ciertos comportamientos y por el manejo de la marotte, del matapecados o rabo de zorro, cuando no de un mero bastón, así como por su repetida asociación al gallo y su semejanza con el "hombre salvaje", también provisto de clava y cargado de connotaciones animales y eróticas ${ }^{4}$.

Sin embargo, más destacadamente en lo que concierne al bobo, algunos de estos "locos" manifiestan una carencia de virilidad obvia, e incluso adoptan posturas y características más o menos femeninas: si el bobo es buey, como lo quería Covarrubias, no resulta asombroso que muchas veces revista el traje de mujer ${ }^{5}$,

${ }^{4}$ De la rica literatura historiográfica y crítica relativa al bufón, sólo destacaré la reciente obra de $\mathrm{M}$. Lever, Le sceptre et la marotte. Histoire des fous de cour, Paris, 1983; por lo que respecta a los mentados accesorios, véanse los sugestivos ensayos de F. MárQuez Villanueva, "El caballero del verde gabán y su reino de paradoja", Personajes y temas del "Quijote", Taurus, Madrid, 1975, sobre todo pp. 219-227; y EugENIO AsEnsio, Itinerario del entremés, Gredos, Madrid, 1965, pp. 20-24. Este último se centra en el personaje propiamente teatral del simple de los entremeses, que tampoco es una figura homogénea, ya que se descompone en pastor, sacristán, criado gracioso, etc., protagonistas afines, pero no del todo idénticos y muchas veces nada locos, por cierto. RAINER HESS generaliza demasiado al identificar al "bobo" con el "fol" del teatro religioso (El drama religioso románico como comedia religiosa y profana, trad. $\mathrm{R}$. de la Vega, Gredos, Madrid, 1976, pp. 238-248, "Bobo y Fol").

5 Cf. J. CanavagGio, "Los disfrazados de mujer en la Comedia", La mujer en el teatro y la novela del siglo xvii. Actas del 'Segundo Coloquio del GESTE, Toulouse, Université de Toulouse-Le Mirail, 1979. Sobre el proceso de afeminamiento de un rey que se dice a sí mismo "bobo e inocente", véase A. LEwIs GalaNES, "El monje-rey y la mujer-varón en La campana de Aragón de Lope de Vega", en M. Criado de Val (ed.), Lope de Vega y los origenes del teatro español, Edi-6, Madrid, 1981. 
y que cierta ambigüedad sexual le parezca a alguno que otro crítico un componente esencial del "arquetipo popular" del que derivarían personajes tan dispares como Sancho Panza o el Juan Tonto de los cuentos folklóricos ${ }^{6}$. También se ha querido descifrar en el universo literario-lúdico de la sottie la aplicación de un código secreto que entraña constantes referencias a la inversión sexual?.

Queda bien claro que en este apareamiento de las actividades mentales y sexuales, y en la consecutiva adecuación de una deficiencia en el raciocinio con una carencia de virilidad (ya que, según una concepción multisecular, el varón y el buen razonar son moderadamente calientes, mientras que el desvariar y la mujer son fríos y húmedos), se puede detectar la manifestación de una ideología dominante falócrata y falocéntrica. En esta circunstancia, todo esfuerzo por anular a tal o cual tipo de individuo, incluso a una clase social entera (caso que se da, por ejemplo, con los rústicos del entremés y de la comedia barroca, blanco de las burlas despiadadas con que se refocila un público urbano y aristocrático), implica necesariamente poner en entredicho la virilidad de las personas y de los grupos a los que cabe mantener en estado de inferioridad y subordinación.

Sin embargo, no por eso dejan de existir, en las mismas entrañas de la "cultura folklórica", los vestigios de un complejo de ideas no explícitas, pero invertidas en imágenes, ficciones y secuencias rituales, y que, por lo tanto, no se reducen a actualizaciones de un arquetipo socio-psicoanalítico abstracto: ideas según las cuales los atributos y comportamientos "femeninos", al ser adoptados por un hombre, no implican ninguna negatividad. Se trata, en tal caso, de una feminidad deliberadamente asumida,

${ }^{6}$ Ésta es la postura de M. Molho, que quiere ver en Sancho y Juan Tonto encarnaciones de un arquetipo reversible (el "tonto-listo" o "necio-astuto"), cuya ambigüedad inicial, mental y sexual, permite un movimiento de inversión revanchista y de afirmación final del varón triunfador ("Raíz folklórica de Sancho Panza", en Cervantes: raices históricas, Gredos. Madrid, 1976, pp. 217 ss.). Consúltese también a Molno sobre el aspecto sexual de esta reversibilidad: "Doña Sancha (Quijote II, 60)", HJMB, pp. 443-448; y sobre algunos ejemplos del hombre-mujer en El retablo de las maravillas, Cervantes..., pp. 176-187.

7 I. Nelson, La sottie sans souci. Essai d'interprétation homosexuelle, Paris, 1977. La demostración, por ser demasiado sistemática, no resulta del todo convincente, pero tiene el mérito de poner de manifiesto un aspecto importante del folklore de los "locos". Compárese con las penetrantes observaciones de C. GaIGnEBET, "Le folklore enfantin du pet", Le folklore obscène des enfants, $\mathrm{Pa}$ ris, 1974, pp. 33-168. 
y aun cultivada, no de una carencia -inicial u ontológica- que se definiría sólo desde el punto de vista de un "machismo" dominante y dominador (tanto el de la sociedad postfeudal como el de la teoría freudiana más o menos adaptada al materialismo histórico). Ideas quizá heredadas de una lejana prehistoria en que, al desconocer el papel del factor sexual en los mecanismos de la procreación, se llegó a pensar que el poder genético estaba difundido y permanecía latente en todos los elementos del cosmos, aunque resultaran privilegiadas las hembras de los animales y las mujeres. Este concepto, junto a la ignorancia real o afectada de la función del semen masculino, a veces considerado mero auxiliar - cuando no de eficiencia nula-, pudo generar el sentimiento de que es al hombre y no a la mujer a quien le falta algo, ya que no es, como ella, capaz de reproducirse. Tanto es así que la "catártica revancha" por la que se realiza el hombre no pasa por la castración simbólica del padre, sino por la apropiación mimética del poder generativo detentado por las mujeres (y superlativamente por la madre $)^{8}$. Esta apropiación se lleva a cabo en ritos y proyecciones imaginarias con los cuales, desde la mera imitación (disfraz femenino) hasta la tentativa de identificación (subincisión), se llega a una suplantación casi efectiva (couvade).

Las representaciones folklóricas del "loco" resultan, por tanto, tributarias de varias capas culturales y de una herencia múltiple: llevan siempre el sello de una negatividad degradante plasmada en las premisas de la ideología patriarcal; pero también vehiculan remotas reminiscencias y retazos de un sistema de asociaciones, acaso más hondamente arraigado que el racionalismo falocéntrico. Este sistema vincula al loco, vector de fuerzas germinales y no desarrolladas, con el tiempo cosmogónico anterior a las diferenciaciones sexuales, anterior incluso a la escisión entre ser y no ser, verdad y error, cordura y desatino: caos y edad de

${ }^{8}$ En términos aún psicoanalíticos, aunque desprovistos de toda complacencia arquetipófila, expresa claramente este concepto BRUNO BETTELHEIM, Les blessures symboliques. Essai d'interprétations des rites d'initiation, Paris, 1971, sobre todo caps. 5, 6 y 7. No deja de ser significativo el que en las historias de Juan Tonto y tipos afines falte por completo toda relación con el padre - figura totalmente ausente- y que sea la madre, o la esposa, el elemento dominante de un binomio exclusivo. Si al final triunfa el tonto, no es porque entrañe un sabio oculto, sino porque, por su misma tontería y dependencia umbilical, se encuentra inmerso en el océano amniótico de las fuerzas generativas o, como decía Covarrubias, porque "A los bobos se aparece la Virgen María"; por eso descubre tesoros y, sin siquiera darse cuenta de ello, supera dificultades ante las que cejan los más sabios. 
oro confundidos en una misma matriz". Este vínculo explica el papel desempeñado por distintas formas de "locura" en los rites de passage, como los practicados en los albores del Año Nuevo (Fiesta de Inocentes, Obispillo, etc.), en el carnaval o en los solsticios, ya que dichos ritos implican una vuelta provisional al tiempo de los orígenes. Y explica también las frecuentes connotaciones genético-andróginas y los procesos de inversión asociados a distintos tipos de "locos": regreso al núcleo primigenio de la vida, al que dan cuerpo la figura burlesca del "hombre preñado" y los partos simulados que entrañan tantos ritos iniciáticos ${ }^{10}$.

\section{Disparates y CUENTOS ERótico-Agonísticos}

1. El motivo del hombre preñado aparece en primer lugar como uno de los múltiples absurdos de que están plagados los "cuentos de mentiras" y "coplas de disparates" "11. Ya se sabe que

${ }^{9}$ Sobre la relación del "loco" o "bufón" del teatro sánscrito (el Vidusa$k a$ ) con el Netherworld cosmogónico, véase F. B. J. KuIPER, Varuna and Vidusaka. On the origin of the Sanskrit drama, Amsterdam, 1979, cap. 2.

10 Por eso puede decirse que la imagen del hombre preñado corresponde a un esfuerzo por superar el proceso de desvirilización, que produce "un tipo único de infrahombre esterilizado, incapaz por definición de procrear, fisiológica y moralmente" que M. MolHo, Cervantes..., p. 185, define a partir de los "castrados", "capachos" y "repollos" del retablo cervantino. Pero no se trata de superarlo mediante un acceso a la dominación fálica, sino por el desarrollo de las promesas genéticas implícitas en el componente femenino que connota el "repollo" (ibid., pp. 182 ss.). Sobre el trasfondo andrógino de toda una serie de mitos y rituales relativos al travestismo y a la bisexualidad y su relación con los estratos más arcaicos del pensamiento religioso, véanse MirceA Eliade, Méphistophélès et l'Androgyne, Gallimard, Paris, 1962, pp. 95-154; Naissances mystiques, Gallimard, Paris, 1959; M. Delcourt, Hermaphrodite, Paris, 1958; H. Baumann, Das doppelte Geschlecht, Berlin, 1955; W. D. O'Flaherty, Women, Androgynes, and other mythical beasts, University of Chicago Press, Chicago, 1980. Sin embargo, no cabe atenerse a un tipo demasiado general y abstracto de antropología religiosa, so pena de caer otra vez en la manía hermenéutica de los arquetipos: pueden ser de consulta provechosa estudios más focalizados, como L. BRISson, Le mythe de Tiresias. Essai d'analyse structurale, Leyde, 1976; G. Hamonic, "Travestissement et bisexualité chez les 'Bissu' du pays Bugis", Archipel, 10 (1975), 121-134, que recalcan, el primero a propósito de un conjunto de mitos y el segundo de una institución ritual, el aspecto esencialmente positivo y la función sagrada de cierto tipo de afeminamiento del varón. En otro trabajo estudiaré el tema folklórico del hombre que cambia de sexo.

${ }^{11}$ Sobre esta clase tan peculiar de cuentos, véanse: C. NARCiSs, Lügenmärchen aus alter und neuer Zeit, Stuttgart, 1962; P. N. BoratAV, 'Le 'Tekerleme'. 
entre las retahílas de adynata o impossibilia, figurativas del “mundo al revés" y ensartadas en las coplas y cuentos de esta clase, se presentan y multiplican varios tipos de inversiones, alianzas de contrarios y trastrueques, entre los cuales hay que destacar unos imposibles genéticos (como el que una mujer dé a luz un pollino ${ }^{12}$ ), menciones de intercambios de atributos y funciones sexuales ("vi las mujeres con barbas / e los hombres con tocados' ${ }^{13}$ ) y, por supuesto, alguna que otra alusión a una preñez masculina ("Era el caso averiguar / De que murió don Simón: / Si de parto o sarampión" "14).

Este burdo fárrago de descabelladas asociaciones y mentiras enormes, a veces simétricamente dispuestas y engastadas en un esbozo de escenario, constituye el marco formulario de la sottie originaria y el repertorio interlocutivo de esos "locos" específicos que son los gaudisseurs y sots que se desafían y contradicen, a cual más desatinado ${ }^{15}$. Al estudiar los temas que se entreveran en estos juegos agónicos, no dejaremos de constatar que en muchos casos se relacionan con el concepto subyacente de un universo a la vez caótico y paradisiaco (países de ficción, tierra de Cucaña, mundo al revés ${ }^{16}$ ), y que son atravesados recurrentemente por imágenes germinativas y cosmogónicas, como la del huevo gigan-

Contribution a l'étude typologique et stylistique du conte populaire turc', $\mathrm{Ca}$ hiers de la Société Asiatique, 17 (1963), ampliamente reseñados por A. DE FELICE ("À propos des contes de mesonges", Arts et Traditions Populaires, 12, 1964), también autora de "Les joutes de mensonges et les concours de vantardises dans le théâtre comique médieval et le folklore français" ( $A C E, \mathrm{t}$. 2). Las copias de disparates han sido objeto de importantes estudios, como el artículo del siempre precursor J. AMADES ("El habla sin significado y la poesía disparatada", $R D T P, 15,1959)$ y los trabajos de síntesis de Porter y Zumthor sobre la fatrasie. También se han interesado en el tema M. Chevalier y R. Jammes, Mélanges M. Bataillon, Féret et Fils, Bordeaux, 1962; remitiendo a las anteriores recopilaciones de R. Foulché-Delbosc en $R H i, 9$ (1902); 10 (1903); 33 (1915), y B. Periñan, Poeta Ludens. "Disparate", "perqué" y "chiste" en los siglos xvi y xvii, Giardini, Pisa, 1979.

${ }^{12}$ Este motivo, del que J. Camarena me dice que todavía pervive en la tradición oral castellana, fue usado por LOPE DE VEGA en El lacayo fingido, ed. C. Bravo-Villasante, Taurus, Madrid, 1970; véase J. Cano-Ballesta, "Los graciosos de Lope y la cultura cómica popular de la tradición medieval", en Lope de Vega y los orígenes..., pp. 777-783.

${ }^{13}$ Cit. por Foulché-Delbosc, RHi, 33 (1915), p. 414 (versos 105-106 de las "Coplas de unos disparates nuevamente compuestos"). Cf. B. PERIÑAn, op. cit., pp. 45-46.
${ }^{14} \mathrm{~J}$. AMADES, op. cit., p. 289 a.
${ }^{15}$ A. DE FELICE, "Les joutes de mensonges...", pp. 44, 56 ss.
${ }^{16}$ Cf. ibid., pp. 60 ss. 
tesco, la del horno donde se plasman las personas, la de la cerda hilandera y la del eje en el que cabe sentar las bases del mundo ${ }^{17}$.

2. Con mayor intensidad y precisión se desarrolla el motivo del parto imposible en algunos cuentos cuyo tema básico es el enfrentamiento entre una persona de condición más o menos subalterna (generalmente una chica astuta o un adolescente en situación de fuerte dependencia respecto a un pariente, jefe o rey) y un representante de la autoridad y del poder, por lo general un soberano presumido o abusivo. Este hace alarde de su superioridad estatutaria imponiendo a uno de sus súbditos una prueba imposible o proponiéndole un enigma indescifrable, más o menos análogos, por su contenido temático, a los absurdos e incompatibilidades de los cuentos y coplas de disparates. Pero interviene la hija del desgraciado: mediante respuestas agudas o contrapruebas capciosas consigue desconcertar al soberano, poniendo de manifiesto lo absurdo de sus supuestos y exigencias. Así se hace patente la derrota del más poderoso por el más débil, aunque muchas veces el cuento acaba con una reconciliación y una boda, que vienen a zanjar las oposiciones entre ambos extremos ${ }^{18}$.

Ahora bien, muchas de las pruebas estrafalarias impuestas por el rey en los cuentos de este tipo estriban en transgresiones de diferencias sexuales e imposibles genéticos: se trata, por ejemplo, de ordeñar un toro o de hacer que el mismo toro dé a luz ${ }^{19}$, o de empollar huevos duros ${ }^{20}$. En tipos de cuentos distintos, aunque estrechamente relacionados con los anteriores, pues intercambian con ellos motivos y secuencias, el propietario de un lagar reclama que le pertenece el potro nacido de una yegua que pasó la noche cerca de dicho artefacto, aduciendo que éste es responsable, o in-

17 Ibid., pp. 57, 73, 77 y 80-81, respectivamente.

18 Se trata del tipo 875 de la nomenclatura de Aarne y Thompson: "The clever peasant girl", y de los tipos afines (desde 875A hasta 875E), en A. AARNE y S. THOMPSON, The types of the folktale, Suomalainen Tiedeakatemia, Helsinki, 1973 (FF. Communications, 184), p. 293-297. Este ciclo ha sido objeto de un estudio completo: J. DE VRIEs, Das Märchen von Klugen Rätsellösern, Suomalainen Tiedeakatemia, Helsinki, 1928 (FF. Communications, 73). Preciosa versión en J. Amades, Folklore de Catalunya. Rondallística, $2^{\mathrm{a}}$ ed., Selecta, Barcelona, 1982, pp. 998 ss., núm. 401 ("La filia del carboner"). -En adelante, al referirme a la nomenclatura de Aarne y Thompson, lo haré por Aa-Th.

19 Motivos H 1024-1 y H 1024-1-1 (S. ThOmPSON, Motif-index of FolkLiterature, Indiana University Press, Bloomington, 1955-1958, 6 ts.). Véase en particular los tipos $875 \mathrm{~B}$, “Bull's milk", y $875 \mathrm{~B}$, “Bull's calves".

${ }^{20}$ Ibid., motivo H. 1023-1. 
cluso autor, del parto ${ }^{21}$. En una serie de narraciones muy difundidas en África se da la situación, más verosímil, de un enfrentamiento por la propiedad de un potro o de una ternera recién nacidos, entre el dueño del caballo o del toro que hizo de semental y el propietario de la hembra que alumbró.

Es evidente que, en este caso, se trasluce el debate que fundamenta esta clase de ficciones: se trata de una oposición entre conceptos patrilineales y matrilineales de descendencia, tensión que entraña graves problemas de herencia y de clasificación social ${ }^{22}$. La narración tiende a demostrar que el que un hijo pertenezca a su padre y no a su madre es tan absurdo como afirmar que es el macho el que pare. En efecto, en dichos cuentos, así como en varias versiones del ciclo de la muchacha astuta, la presunta víctima del torcido raciocinio o perversa fantasía que pretende imponer el cacique abusivo, da al traste con los designios del opresor por una verdadera reductio ad absurdum ${ }^{23}$ : finge que su propio padre acaba de parir (o cualquier otro imposible), lo que no deja de suscitar el incrédulo asombro del contrincante, que se ve obligado inmediatamente a admitir la ineptitud de sus anteriores pretensiones o asertos ${ }^{24}$.

3. El cuento, en esta forma, no parece estar muy difundido en la Península Ibérica. En cambio, se han recogido varias versiones españolas de un tipo afín que comparte con él algunos motivos parecidos a los que nos ocupan: se trata de "La mata de

${ }^{21}$ Tipo 875 E. "The unjust decision: The oil press gives birth to a colt".

${ }^{22}$ Este ciclo de cuentos ha sido estudiado ampliamente (en lo concerniente al ámbito africano), por D. PAulme, "Le mâle qui met bas et les personnage de l'enfant malin", en La mere dévorante. Essai sur la morphologie des contes africains, Paris, 1976, cap. 8 (véanse en particular pp. 190-191 y 240, sobre la relación de estos cuentos con el sistema de parentesco: "L'abus réside...dans la prétention qu'un mâle puisse mettre bas: les petits d'une femelle appartiennent à son maitre et à lui seul. N'y a-t-il pas contradiction entre cet usage admis par tous pour les animaux et, d'autre part, le principe pour les humains d'une filiation en ligne paternellet?', p. 191).

${ }^{23}$ Cf. Motivos H 952 y H 1024.

${ }^{24}$ Cf. Tipo 875 B.l y D. Paulme, op. cit., passim. En el cuento catalán recogido por Amades no se alude a un parto masculino, sino a la eventualidad de pescar sardinas en un pueblo, lo que permite a la "filia del carboner" demostrar la insensatez de lo sentenciado por su marido, el rey: "Tan possible es pescar aquí sardina com que un cavall faci una pollina". En un cuento de Jalisco recogido por H. T. WHEELER, Folktales from Jalisco, American Folk-Lore Society, Philadelphia, 1943, p. 85, el diablo insta al héroe a que ordeñe un toro: la esposa del despistado le resuelve el problema aconsejándole que diga que parió su compadre. 
albahaca"25. Una de las pruebas impuestas por el rey es que la muchacha se presente "doncella y preñada", lo que ella rebate con aserciones igualmente desatinadas. Las versiones españolas son de especial interés por manifestar el sistema de competición alternativa en el que se ensartan enigmas y agudezas, presentadas en forma de preguntas y respuestas, ataques y contraataques, y por el contexto festivo y erótico de un juego prematrimonial que se propone reducir progresivamente las barreras que separan a los protagonistas y preparar la unión final. El argumento principal resulta ser el mismo que el que impera en las justas y concursos de mentiras y disparates de la sottie medieval: se trata de una puja agonística, en la que cada uno se esfuerza por reducir al silencio a su opositor y obligarlo a confesar su incapacidad de mejorar los alardes imaginativos ya sacados a relucir. Claro está que el cuento implica una vuelta final a la realidad (es decir, la diferencia entre especies y sexos y el equilibrio que permite la convivencia entre poderosos y humildes y el ajuste entre sistemas opuestos de descendencia; o sea, la ley en sus acepciones naturales y sociales $\left.{ }^{26}\right)$. Al contrario, en el universo del disparate se da rienda suelta a la fantasía y a los encadenamientos más descabellados, siendo el objeto del juego verbal desquiciar todas las congruencias que dan al mundo configuración estable, para reanudar el contacto con el caos primordial, cuya pujanza y fuerza de (re)generación sólo puede entreverse a través de una "locura" absoluta.

Pero a pesar de esta distinción, se advierte claramente el en-

${ }^{25}$ Tipo 879, "The Basil Maiden". Encabeza la colección de A. M. EsplNOSA, Cuentos populares españoles, $2^{a}$ ed., C.S.I.C., Madrid, 1946-1947, núms. 1-4. Muchas veces se confunde con el tipo 875 (cf. J. B. RAEL, Cuentos españoles de Colorado y Nuevo Méjico, $2^{\mathbf{a}}$ ed., Museum of New Mexico Press, Santa Fe, 1977, núms. 1-2).

${ }^{26}$ Por tanto, la afirmación absurda sólo sirve para resaltar la anuencia a la norma racional, a la regla física y al códico social: no es más que una transgresión verbal y provisional destinada a poner de manifiesto un abuso que amenaza la circulación armoniosa de los cambios y reciprocidades. D. PAulme, op. cit., p. 196, expresa con fuerza y claridad la lógica de este mecanismo: “...tous ces contes qui relatent la victoire d'un héros désarmé sur un adversaire puissant observent à peu pres la même démarche. Voyant poindre un rival dont il croit d'abord pouvoir se défaire aisément, le chef lui impose à cet effet plusieurs tâches impossibles, l'accouchement d'un mâle n'étant que l'une d'entre elles; mais chaque fois l'enfants oblige son ennemi à dénoncer lui même le caractère arbitraire et donc odieux du pouvoir ainsi exercé". No cabe en ello ningún revanchismo revolucionario, ya que la puja transgresiva sólo sirve para restablecer un orden comprometido por un desarreglo excepcional. Las versiones europeas subrayan este conformismo de fondo al sexualizar el conflicto y rematarlo con una boda feliz. 
tronque de unas y otras ficciones en un conjunto de imágenes y representaciones que sirven de contrapunto al concepto de un mundo ordenado y erizado de diferencias, incompatibilidades y barreras. El enlace entre la muchacha astuta de los cuentos aludidos y el loco de las fabulaciones disparatadas lo encontramos en las versiones en que el papel de la heroína lo desempeña un bufón (y consejero) del emperador Akbar, Birbal, al que hacen protagonista de tantas patrañas y chascarrillos. Se ve en la obligación de proporcionar leche de toro al emperador, pero su hija le permite eludir la dificultad al afirmar ante Akbar que su padre acaba de dar a luz y al redargüir al monarca, que no lo quiere creer, que no es esta aserción más absurda que la pretensión de sacarle leche a un toro ${ }^{27}$. La violencia que se le hace aquí al subalterno no es más que un medio de darle la oportunidad de hacer renovado e indirecto alarde de la locura graciosa que alegra a los soberanos.

4. Vemos, pues, que lo que se pone en juego en estas competiciones de locas invenciones, en las que se plasma la imagen del hombre preñado, es el restablecimiento de un equilibrio y de una comunicación entre polos opuestos: poderosos y humildes, sexo masculino y sexo femenino. La evocación provisional de lo imposible (es decir, la procreación sin conjunción de los sexos, la armonía social sin reciprocidades), recuerda la existencia de las diferencias - cada elemento aislado tiene sus prerrogativas y aptitudes propias - y enseña la necesidad de su colaboración, ya que toda producción social o biológica moviliza componentes complementarios. El estado de indiferenciación o de reversibilidad absoluta que se finge postular, por ejemplo, al poder cada sexo atribuirse las características y funciones del otro, sólo serviría, a fin de cuentas, para paralizar los intercambios y esterilizar la vida misma. Los imposibles genéticos son, por lo tanto, ilustración de incompatibilidades: dan cuerpo a diferencias, separaciones e incluso rivalidades. Pero al mismo tiempo, al ponderar la inviabilidad de un universo compuesto de mónadas independientes,

${ }^{27}$ Nótese que Birbal no es ningún tonto-sabio o necio-astuto, sino un personaje muy atinado (distinto del famoso Buhlul, bufón de Harun al Rashid, al que también se le ha atribuido multitud de ocurrencias y aventuras graciosas, ya que en él alternaban momentos de demencia y de extrema sabiduría y sutileza): le atribuyen juicios salomónicos y competencias de superministro imperial. La mencionada anécdota se encuentra en: Somadeva, Kathā Sarit $S \bar{a}$ gara (The Ocean of Story, tr. Twaney-Penzer, London, 1923, t. 5, pp. 64-66 "Note on the 'impossibilities' motif'). 
se demuestra la ineptitud de todo esfuerzo por independizarse.

Sólo puede cumplirse este propósito recurriendo a representaciones arcaicas de un universo indiviso, anterior a todas las escisiones, en el que por todas partes fluye el principio vital y son posibles todas las transformaciones, y poniendo en evidencia al mismo tiempo lo absurdo de esta fantasía y lo abusivo de las utilizaciones que se pueden hacer de ella. No hay forma de superar dicha contradicción. Bien como expresión de la ignorancia de la función ejercida por el varón en la generación, bien como negación del carácter parcial e incompleto de esta función (y, por tanto, de lo imprescindible de la cooperación con el elemento sexual complementario), el mito o fantasma del hombre preñado entraña el doble y contradictorio afán de restaurar una conexión con un primigenio estado de totalidad y omnímoda compatibilidad y transparencia, y de afirmar, a veces en tono de agonística reivindicación del privilegio genético y consiguiente primacía moral (y política), la independencia masculina y la hostilidad hacia un supuesto, acaso imaginario, matriarcado opresor. A la vez rechazo de las barreras entre los sexos y argumento en la polémica que los opone.

Al negar el dualismo y no admitir el carácter incompleto del individuo separado, se proyecta la imagen fantástica de un mundo homogéneo que seguiría manteniendo en pie el estado cosmogónico de indiferenciación. Pero esta postura puramente mágica impediría el paso del caos al cosmos organizado porque, al pretender cada elemento concentrar en sí las potencialidades del conjunto, no cabría reciprocidad y, a fin de cuentas, se crearía una red de tensiones entre individualidades autosuficientes, y pronto rivales, por su pretensión de encarnar la totalidad cada una por separado. El retorno a lo indiferenciado vendría a suponer y a reforzar un proceso agonístico de autoaislamiento. Tanto es así que la figura del hombre embarazado, aunque fundada en la unidad andrógina de los orígenes, viene a ser un medio privilegiado para denunciar lo contradictorio, antisocial y estéril de sus propios supuestos.

Monstruo conceptual, reunión ficticia de incompatibilidades, el motivo que nos ocupa no se reduce, sin embargo, a su dimensión conflictual: hemos visto que forma parte de un repertorio de diálogos lúdicos de función esencialmente erótica, ya que, por su propio carácter de competición agonística, permiten entablar una comunicación, en son de simétrica reciprocidad, entre adversarios destinados, al fin y al cabo, a reconciliarse. El concurso de absurdos de contenidos sexuales viene a ser tanto manifestación 
y exaltación de antagonismo, como medio de relativizar y reducir progresivamente esta oposición inicial: este afán de mediatización se lleva a cabo gracias a una ritualizada y escalonada serie de inversiones e intercambios de papeles y atributos, fingiendo momentáneamente cada sexo que se apropia de las características del otro y que impone a su contrincante humillaciones susceptibles de demostrar (y forzarle a admitir) su incapacidad de prescindir del polo complementario.

Harto conocida es la función del travestismo, de la captación de emblemas del sexo contrario y de las inversiones fingidas en ritos y juegos nupciales y prenupciales: en el cuento de "La mata de albahaca", por ejemplo, la muchacha astuta se disfraza de médico e inflige a su enamorado antagonista la jugarreta del "nabo en el culo" (u otra mala pasada igualmente desvirilizadora), como réplica al beso que el atrevido galán le había robado ${ }^{28}$. En algunas versiones, como para completar la simetría, es el mismo galán quien se disfraza de mujer y consigue así penetrar en el recinto donde están recluidas las muchachas ${ }^{29}$. Cambiando atributos y vestidos ${ }^{30}$, proponiéndose mutuamente enigmas y pruebas de carácter más o menos simbólicamente sexual, que recalcan la inevitabilidad del coito $^{31}$, los protagonistas del dialéctico juego van cercenando poco a poco las barreras que separan el universo masculino del femenino, aprendiendo así cada sexo a definir su propio ethos y a situarse respecto a su necesario complemento. Así pues, la imagen del hombre preñado desempeña un papel transi-

${ }^{28}$ Cf. A. M. Espinosa, op. cit., núms. 1-4.

${ }^{29}$ Ibid., núms. 37-38 y J. A. SÁnchez PÉrez, Cien cuentos populares, Saeta, Madrid, 1942, pp. 429-430 (nótese que el galán disfrazado de vieja les ofrece higos a las doce muchachas: este fruto, símbolo sexual femenino muy tradicional, es simétrico al fálico nabo o rábano de "La mata de albahaca"). Véase R. S. BogGS, Index of Spanish folktales, Suomalainen Tiedeakatemia, Helsinki, 1930 (FF Communications, 90), p. 116, núm. 970. Existe en el romancero todo un ciclo del galán disfrazado de mujer que consigue introducirse, gracias a dicha estratagema, en la torre donde se guarece la altiva princesa a la que se propone seducir (véase Samuel G. Armistead y Joseph H. Silverman, Folk Literature of the Sephardic Jews, University of California Press, Berkeley, 1971, t. 1, p. 279). Estudiaré este tema en otro lugar.

${ }^{30}$ Cf. BoGGs, op. cit. (tipo 857: un cuento español, con mutuo cambio de vestidos de los amantes). Hay equivalentes indios en el ciclo de las narraciones relativas a los prototípicos amores de Krishna y Radha.

${ }^{31}$ Cf. en el tipo 875, el motivo del mortero sin mano, y en los cuentos africanos mencionados, la prueba que consiste en comer el arroz contenido en un recipiente sin quitar la tapadera (PAulme, op. cit., pp. 201-202), requisito parecido al que se exige a la muchacha que ha de llegar "doncella y preñada". 
tivo: aducida para ser inmediatamente rebatida como eventualidad a la par integradora y desintegradora, aparece como construcción deliberada y conscientemente ficticia y lúdica (como las inversiones carnavalescas y las evocaciones imaginarias y escapistas del tiempo cosmogónico), y alimenta controversias y conflictos al mismo tiempo que interviene en los procedimientos y ritos asociativos por los que se van mediatizando y resolviendo los $\operatorname{mismos}^{32}$.

\section{LOCOS CLUECOS Y TONTOS PONEDORES}

1. Según una hipótesis etimológica probablemente errónea, la palabra loco tendría una relación con el nombre de la gallina clueca: se supone, en esta perspectiva, que la locura se asemeja a la vacuidad del huevo huero o podrido (llamado precisamente, loco en algunas partes) empollado por la clueca. Se podría reforzar la comparación con otra que estriba más bien en la inmovilidad de la gallina clueca, que explicaría la sinonimia de "clueco" y enfermizo, y evocaría la imbecilidad o el estupor del supuesto loco. Por último, el doble sentido de adjetivo chocho, que deriva más claramente de "clueca" y que se puede aplicar tanto al huevo podrido (en portugués) como al viejo estúpido, podría confirmar dicha teoría que más nos interesa aquí por las asociaciones imaginarias y simbólicas que entraña, que por su hipotética exactitud filológica ${ }^{33}$. No dejaremos, por tanto, de recordar que "chocho" designa también el órgano genital femenino y que, como apunta el propio Corominas, "en ambientes rurales no es raro que se aproveche al enfermo para incubar huevos" 34 .

Por el momento, nos contentaremos con retener la asociación del loco o tonto con la clueca y con los huevos, así como las connotaciones femeninas que implica dicha asociación.

32 En el cuento de "Sapia Liccarda" (Pentamerone III, 4), que pertenece al mismo tipo (Aa-Th 879) de "La mata de albahaca", se da explícitamente el motivo del hombre que cree haber alumbrado, ya que el ogro en cuyo jardín acaba de caer la heroína se imagina que ésta nació de su recién escapada "ventositá".

${ }^{33}$ Véase en J. Corominas, DCEC, s.v. loco, chocho y clueca. También se puede consultar M. L. WAGNER, "En torno a las etimologías españolas de G. Rohlfs", RFE, 11 (1924), pp. 268 ss., a propósito del "ovo choco" portugués.

34 Corominas, DCEC, s.v. clueca. También I. NAGEL, Die Bezeichnungen für "dumm' "und "verrückt" im Spanischen, M. Niemeyer, Tübingen, 1972, p. 112, s.v. chocho. 
Otra red semántica ha sido trazada por $\mathrm{G}$. Rohlfs, que relaciona el portugués ovo choco (huevo huero) con el cuclillo, por alusión a la consabida creencia en los huevos puestos por dicho pájaro en los nidos ajenos ${ }^{35}$. Sin embargo, parece que con ello seguimos en el mismo simbolismo, ya que son bien conocidos, por una parte, la relación del cuco con los maridos engañados y, más generalmente, con la idea de impotencia y esterilidad ${ }^{36}$, y por otra, la supuesta tontería del cuco $^{37}$.

No me parece inverosímil, además, que la posición "en cuclillas", expresión indudablemente derivada del nombre de la "clueca", infiera implícita alusión al "cuclillo" y a su víctima, la curruca $^{38}$. Apuntaremos, por fin, para apurar el instructivo encanto de las falsas etimologías, que lo mismo que el grotesco "zambapalo" fue probablemente danza de "zampapalos" (o sea, necios), la chilena "zamacueca" bien pudo ser baile de "zamacucos", y que algún filólogo a la violeta ha querido ver en ella una "zamba clueca" ("por la posición casi en cuclillas que a menudo adopta el varón", 39 ).

No cabe aquí internarse más en el terreno del simbolismo tradicional y folklórico de gestos, ademanes y posturas relacionados con la locura (ni en el de sus connotaciones zoológicas y, más destacadamente, ornitológicas): bastará con observar que, cómicas o infamantes, el loco o mero bobo es encrucijada de alusiones sexuales, y tiene un vínculo estrecho y contradictorio con la genética oval ${ }^{40}$.

${ }^{35}$ G. Rohlfs, "Etimologie spagnuole", ARom, 5 (1921). Véanse los comentarios de M. L. WAGNER, op. cit. Se pasaría del concepto de huevo sustituido al de huevo falso, sin fecundar, huero.

${ }^{36}$ Cf. WAGNER, op. cit., p. 269 (en provenzal, kugieu significa "cuclillo", pero el iou kugieu es un huevo no fecundado. Es probable que esta homonimia también tenga relación con la costumbre atribuida al cuco). Nótese que el tema de la castración aparece en las leyendas relativas al cuco, cf. P. SÉBILlot, Le folklore de France, Paris, 1968, t. 3, pp. 163-165.

37 Cf. I. NAGEL, op. cit., p. 119 ("más tonto que un cuco").

${ }^{38}$ Ya que la forma normal debería seguir igual al anticuado "en cluquillas". Hay que observar que ponerse "en cuclillas" es lo mismo que "acurrucarse", o sea, adoptar la posición de la curruca. Apunta Covarrubias (cuclillo) que la curruca es "tan simple que saca los huevos de qualquier otra (avecica) poniéndoselos en su nido", y que el cuclillo "derrueca en el suelo del nido abaxo los huevos de la corruca, o se los come, y déxale allí los suyos para que se los saque y críe. Esto mismo haze el adúltero..." Véase también cuclillas y cuclillo en DCEC, y acorrucarse y cornudo en CovarRubias.

${ }^{39}$ Véase zamacueca en $D C E C$.

40 Debe de enlazarse con alguna tradición folklórica de Europa central que todavía no he podido rastrear, el espectáculo recién estrenado del teatro de 
2. Este complejo de asociaciones queda actualizado en una serie de motivos narrativos y cuentos especialmente arraigados en el mundo mediterráneo. Ya en la Edad Media la imagen del hombre que empolla huevos servía para ridiculizar a tal o cual individuo, grupo o categoría: en la literatura francesa, desde el siglo XIII, se va repitiendo el tópico del anglais qui couve, de tono claramente satírico y xenófobo, y se critica al caballero recreant comparando su inactividad y presunta cobardía con la actitud de la gallina clueca ${ }^{41}$.

Aparece también, alguna que otra vez, el motivo figurado del hombre que empolla (¿O pone?) huevos en el mundo de las misericordias que adornan las sillerías de coro en las iglesias y catedrales: se puede ver en Saint Seurin (Burdeos) y en la catedral de Toledo ${ }^{42}$. En casos de esta clase es difícil determinar si el tema entraña una alusión más o menos malévola a una costumbre de campesinos $^{43}$, una alegoría satírica y moral ${ }^{44}$, o, lo que me pa-

la Linterna Mágica de Praga, cuyos protagonistas son dos dioscúricos payasos nacidos de sendos huevos, y que no se expresan sino por silbidos. (Cf. AarNEY y THOMPSON, op. cit., tipo 650, "Strong John", y motivo F 611-1-11 "'Strong hero born from egg").

41 Véase A. LANGFors, ' $L$ 'anglais qui couve dans l'imagination populaire der moyen âge", Mélanges Hoepffner, 1949, pp. 89-94. Es corriente todavía en castellano y francés, llamar al cobarde "gallina" o "poule mouillée". Nótese que varios ejemplos de los que cita Langfors se encuentran en fatrasies o sottes chansons (cf. supra 1-1). Entre las citas comparativas que recoge el autor, obsérvese que figura explícitamente el motivo del hombre embarazado: "...li rois Artus / Estoit gros de vif enfant' (Fatrasies d'Arras, s. XIII).

${ }^{42}$ Información oral proporcionada por Henry Kraus. La misericordia de Saint-Seurin está reproducida en D. y H. KRAUS, The hidden world of Misericords, New York, 1975, núm. 40. El motivo no parece haber sido comentado por I. Mateo Gómez, Temas profanos en la escultura gótica española. Las sillerías de coro, Madrid, 1979.

${ }^{43}$ Costumbre parecida a la que menciona Corominas (cf. supra, nota 34). Juan de Pineda, Diálogos familiares de agricultura cristiana, BAE, 162, p. 63, alude a "diversas maneras de empollar los huevos" (sembrados en tierra o en estiércol, o incubados por una mujer: "...echaré doscientos o trescientos huevos a mi mujer y la haré sentarse sobre ellos en grande escriño de paja, y tendré pollos para todo el año bien baratos'). Nótese sus alusiones eruditas a prácticas o cuentecillos que saben a adivinación o magia: la emperatriz Livia, para conocer el sexo del niño del que estaba embarazada, "traía muy abrigado un huevo entre los pechos, hasta que a su plazo natural de las tres sernanas, le empolló y nasció dél un pollo y ella parió a Tiberio"; en Sicilia "floreció un bebedor que soterraba los huevos y bebía hasta que salían los pollos dellos"' (diálogo VI, cap. 31).

${ }^{44}$ En las misericordias españolas abundan las alusiones al tópico del “mundo al revés" (cf. I. Mateo Gómez, op. cit., pp. 291-294), así como re- 
rece más probable, la reminiscencia jocosa de un cuentecillo análogo a los que mencionaremos a continuación.

No cabe duda que, por lo general, el significado es de burla y reprobación, no desprovisto, a veces, de claras implicaciones diabólicas, como sucede en las alusiones de Gautier de Coinci a los béguins et papelarz, hipócritas y sodomitas, que celebran feste saint Pançart y ponen huevos que empollará el diablo y de los cuales nacerá el Anticristo ${ }^{45}$. Sabido es, por otra parte, que en el folklore germánico los demonios se alimentan con huevos, y que ellos mismos van poniendo otros tantos, que luego regalan a las mujeres a las que han poseído: ponen las brujas en Suiza, y se cuentan en Alemania graciosas anécdotas de monjes y labradores que, habiendo comido dichos huevos, se vuelven también ponedores ${ }^{46}$. La gente diabólica es aficionada a los "huevos de gallos", empollados por brujas, de los que salen personajes sobrenaturales como el coqwergi alpino (especie de enano salvaje), o peligrosos monstruos como el cocatrix o el basilisco ${ }^{47}$.

3. Más inocuo es el tradicional bobo empollador de una secuencia narrativa (que a veces constituye un cuentecillo por sí sola) difundida en toda el área mediterránea e incluso en Alemania, Hungría, Rusia, etc. En este episodio de ambiente generalmente rústico, el simple, al que imprudentemente la madre o la esposa han dejado solo en casa confiándole algunas tareas sencillas, comete una serie de tonterías más o menos catastróficas, siendo una de ellas el imaginar que los huevos de la gallina o del ganso se van a enfriar si él no los empolla: cumple su propósito (a veces cubriéndose de plumas y cacareando) y se sienta en los huevos, con el previsible resultado de romperlos todos y ensuciarse los

presentaciones simbólicas o festivas de herejías o vicios como lujuria, homosexualidad, locura (ibid., caps. 11, 12, 14 y 17), muchas veces moldeadas con los estereotipos fraguados en el refranero (cap. 5) y en las tradiciones satíricas que se refieren a la relación entre marido y mujer (cap. 16). Sobre el trasfondo polémico de esta iconografía, véase $\mathrm{D}$. y $\mathrm{H}$. KRAUs, Las sillerias góticas españolas, Madrid, 1984, caps. 11 y 12.

${ }^{45}$ De Sainte Leocade, ed. E. Vilamo-Pentti, Helsinki, 1950: "Tex genz se vont plus reponant / Que gelines qui vont ponant... Deable queuvent quanqu'il ponnent / Antecriz naistra de leur wés [huevos]/Souhaidons tuit honte a leur wés", p. 174.

${ }^{46}$ H. BäCHTOLD-STÄUbli (ed.), Handworterbuch des deutschen Aberglaubens, Berlin, 1927-1935, t. 2. p. 605.

47 C.f. P. Sebillot, op. cit, t. 3, pp. 231 y 268 ss., y V. Newall, An Egg at Easter. A folklore study, London, 1971, pp. 69 ss. ("The devil's egg"). 
pantalones ${ }^{48}$. Este tipo narrativo parece estar difundido ampliamente en el mundo musulmán, donde el héroe de la anécdota es Yehá (o sea, Nuredin Hodja) ${ }^{49}$, o Xailún ${ }^{50}$. Se encuentra tambień con frecuencia en Sicilia e Italia, en formas literarias (Morlini, Basile, G. C. Croce ${ }^{51}$ ) y populares ${ }^{52}$, y en la Francia meridional $^{53}$. Las versiones hispánicas forman parte del ciclo relativo a "Juan Tonto", del que tantas historias se cuentan en todas las culturas ibéricas e iberoamericanas: en estas versiones, el simple tiene que entendérselas algunas veces con su madre, otras con su mujer (María la Lista), pero siempre se echa en los huevos de la gallina o de la pava, rompiéndolos y gritando: "Estoy en clo, estoy en clo" 54 . En Cataluña, también la madre de "En Filoseta" encuentra a su hijo assegut damunt de la covadora... i portava tot el darrera empastifat dels ous esclafats ${ }^{35}$. Ya se conoce la significación se-

48 Aa-Th 1218 (Numskull sits on eggs to finish the hatching): la bibliografía de Aarne y Thompson se puede completar con J. Bolte y G. Polivka, Anmerkungen zu den kinder-und-Hausmärchen del Brüder Grimm, Leipzig, 1913-1932, t. 1, p. 316 . Se podrían añadir hoy muchas más versiones. Puede considerarse tipo afín Aa-Th 1677 ("The general hatches out an egg").

49 A. Wesselski, Der Hodscha Nasreddin, Weimar, 1911, t. 2, pp. 111-112 y 212 , núm. 433 , que traduce una adaptación siciliana.

50 V. Chauvin, Bibliographie des ouvrages arabes, Liège, 1892-1922, t. 7, pp. 155 ss., núm. 437 ("Xailloun"). No sólo empolla los huevos de la gallina que acaba de matar, sino que trata de amamantar a una criatura que llora. Al final encuentra un tesoro y se granjea los favores del califa.

${ }^{51}$ El Vardiello de Basile (Pentamerone 1-4) y el Bertoldino de Croce (episodio del "covazzo dell'occa", ed. P. Camporesi, Torino, 1978, pp. 122 ss.) hacen rabiar a sus respectivas madres, pero acaban encontrando tesoros o congraciándose con el rey.

52 S. Lo Nigro, Racconti popolari Siciliani, Firenze, 1958, núm. 1016 ("Giufá e la chioccia"), y G. D'Aronco, Indice delle fiabe toscane, Firenze, 1955, núm. 1226 ("Falchetto") que resumen las versiones recogidas en ambas regiones por J. Pitré. También ·se puede consultar: F. MANGO, "La leggenda dello sciocco nelle novelline calabre", Archivio per lo studio delle trad. popol., 10, pp. 45 ss., cf. pp. 47 ss.: "Juvadi e la jocca".

${ }^{33}$ D. FABRE y J. LACROIX, La tradition orale du conte oceitan, P.U.F., Paris, 1973, t. 2, núm. 57 ("Jan Fotral"), pp. 329-330 y 335 para el episodio que nos interesa.

${ }^{54}$ A. M. Espinosa, op. cit., t. 3, núms. 181-188 (con abundante bibliografía), motivo $\mathrm{Cl}$ (p. 194): véase el episodio mencionado en t. 1, p. 473. En "El anillo de la princesa" (ibid., núm. 147), el tonto se llama Bartolo (cf. Bertoldo y Bertoldino en Italia): “...fue y tiró la llueca del nido y se puso a apollar los güevos. Y se rompieron todos los güevos y ai se quedó con los güevos pegados en el culo", t. 1, op. 352-353. En Nuevo México, Juan Tonto empolla los huevos y grita: “CCáscaras! ¡Cáscaras! Estoy culeco” (J. B. RaEL, op. cit., t. 2, p. 360 , núm. 326).

${ }^{55}$ J. Amades, Folklore..., p. 941, núm. 377 (“En Filoseta”), cuento que 
xual de "los huevos", y es muy probable que la imagen del desastre final represente simbólicamente la impotencia que sigue a un fallido intento (¿ritual?) de acrecentar la propia virilidad por magia de contacto ${ }^{56}$.

4. No hay mucha distancia entre el tonto que empolla huevos y el que los pone de verdad, exceptuando el hecho de que éste es figura de pura ficción. Entre los dos media el que cree que los humanos pueden poner huevos ${ }^{57}$, o el bellaco que finge que los pone para engañar a los que abrigan dicha creencia ${ }^{58}$. De antigua tradición y extensa difusión es el cuento de la mujer incapaz de guardar un secreto: su marido somete a prueba su discreción diciéndole que ha puesto un huevo o que ha parido analmente un pájaro. En pocas horas, claro está, la interesante noticia se ha difundido y se ha multiplicado su contenido. Este cuento se relaciona muchas veces con el de "los tres consejos" (Aa-Th. 910) y aparece en Abstemius, Noël du Fail, los Gesta Romanorum y La Fontaine, así como en la novelística oriental ${ }^{59}$. Preciosas versiones hispánicas, reseñadas por Espinosa, se encuentran en Cataluña, Asturias, Portugal y América ${ }^{60}$. En estas narraciones, al contrario de

remite erróneamente S. Thompson al tipo 1677 (error repetido por FaBRE y LACroIX, op. cit.): para el episodio que nos interesa no es más que otra versión del tipo 1218.

${ }^{56}$ Del mismo modo, los bobos de la comedia a menudo ponen sus partes traseras en contacto con los pitones de un toro, con resultados ridículos (N. SALOMON, Recherches sur le thème paysan dans la "Comedia" au temps de Lope de Vega, Université, Bordeaux, 1965, p. 22). Detrás de este juego burlesco, aún practicado por los enanitos toreros, se oculta verosímilmente un rito arcaico de fertilización parecido a los que estudia A. Álvarez DE Miranda, Ritos y juegos del toro, Madrid, 1962, pp. 115-131.

${ }^{57}$ Cf. Aa-Th. 1434 ("The egg-excreter") y 1464 A ("Bachelor will only marry girl who can lay eggs"); ambos tipos corresponden a cuentos franceses del Canadá. Graciosa burla de trasfondo homosexual entraña la anécdota en que Yehá espanta a sus amigos, que pretendían engañarle haciéndole creer que habían puesto huevos, fingiendo comportarse como un gallo, véase $\mathrm{R}$. Basset y A. Mouliéras, Les fourberies de Si Djeh'a - Contes kabyles, Paris, 1892, p. 87, núm. 13 ("Si Djeh'a et ses amis au bain").

${ }^{58} \mathrm{Aa}-\mathrm{Th} .1381 \mathrm{D}$ ("The wife multiplies the secret"). Motivo J2353.

${ }^{59}$ Véase bibliografia en S. ThOMPSON, op. cit.; y A. M. Espinosa, op. cit., t. 2, p. 287. Para las versiones árabes véase Chauvin, op. cit., t. 8, p. 168, núm. 184 ("La femme et le secret").

${ }^{60}$ A. M. Espinosa, op. cit., núm. 69, "El secreto" (tipo V, t. 2, p. 291). En RaEL, op. cit., núm. 94, se trata de un concurso entre tres hermanos que ponen a prueba la discreción de sus esposas: la del menor, el cual pretende haber puesto un huevo, guarda el secreto y le hace ganar la apuesta. 
lo que sucedía en el caso precedente, la tontería está de parte de la mujer y la hazaña masculina es pura mentira: reaparece el trasfondo agonístico y lúdico de los cuentos y coplas de disparates (cf. la apuesta entre hermanos), pero elaborado según el tópico del matrimonio listo-tonta (inversión de la pareja lista-tonto del tipo anteriormente estudiado).

5. Para acabar con la asociación entre huevos y tontos, mencionaré el cuento del simple que se deja vender una calabaza creyendo que se trata de un huevo de asno o de yegua. Cuando se le resbala la calabaza y va a romperse en una breña, espantando a un conejo o algún otro animal, que huye a todo correr, el tonto cree que el fugitivo bicho es el burro o potro que acaba de salir del huevo ${ }^{61}$. Viene al caso aquí este cuentecillo porque en algunas versiones el tonto empolla dicho huevo, o tiene intención de hacerlo, y sobre todo porque el relato se contamina frecuentemente, por lo menos en el motivo final, con un tipo de cuento distinto, en el que el tonto se cree preñado y piensa que el animal que huye ante él es su propio hijo ${ }^{62}$.

El cuento de los huevos de yegua tiene gran difusión tanto en Oriente como en Occidente (se han recogido muchas versiones en Francia), y tiene forma literaria desde el siglo XVI (J. Pauli, Schimpf und Ernst). También forma parte del repertorio de Yehá ${ }^{63}$, y se emplea con distintos fines: puede expresar el desprecio burlón de la gente de la ciudad hacia los campesinos y serranos $^{64} \mathrm{o}$, al contrario, la reacción del campesino contra una clase dominante que ignora las realidades más elementales de la vida $^{65}$. Sólo conozco una versión ibérica, que es la que recoge Amades, "Els ous de somera', en la que tres babaus son engañados por un hostaler que les hace creer que "en aquell país les someres es covaven" y les vende una carabassa ${ }^{66}$.

61 Aa-Th. 1319 ("Pumpkin sold as an ass's egg").

${ }^{62}$ Cuento que analizaremos a continuación.

${ }^{63}$ Cf. Basset y Mouliéras, op. cit., pp. 123-124, núm. 39 ("La pasteque"); véase p. 42 para la bibliografía de las versiones.

${ }^{64}$ Es lo que sucede en las versiones recogidas en el sur de Francia (FABRE y LACROIX, op. cit., núm. 43, "L'uóu de cavala"). Los habitantes de Carcassonne se burlan de la ingenuidad del "tipe d'un vilatge de la montanha". Aquí el huevo es una piedra y el tonto quiere que su burra la empolle.

${ }^{65}$ En una versión india, es un labrador el que les vende a unos estudiantes bramánicos el supuesto huevo de yegua. F. FAwCETT, "Folktales from I Malabar", Folklore, 26 (1915), p. 417, "The pupils of the Guru", comenta que se trata de "a satire on Brahmans common throughout India".

${ }^{66} \mathrm{~J}$. AmAdes, Folklore..., p. 907, núm. 363. 
Se pueden considerar estos relatos como variaciones sobre un tema tradicional muy difundido, que es la relación entre el tonto (o loco) y la calabaza. Ya se sabe que el calabassot (o carabassot) y el "sandío", como el carnavalesco don Melón del Libro de buen amor, son personajes que tienen relación con una forma de locura. Pero lo que aquí se denuncia, más exactamente, es la confusión entre el huevo y la calabaza. Ambos aparecen con harta frecuencia en las anécdotas de locos, y ambos tienen función genética: no sólo evoca la calabaza - como el huevo huero- una cabeza vacía, sino que está asociada en varias culturas de Asia y África (probables herederas de un fondo subyacente de representaciones prehistóricas) con ideas y creencias relativas al nacimiento y a la cosmogonía ${ }^{67}$. Símbolo femenino y uterino, la calabaza debe ser rota y su destrozo representa a la vez el coito y la creación del mundo ${ }^{68}$.

El origen mítico de esta satírica anécdota se trasluce cuando se la compara con fábulas en las que el nacimiento no es mentira o ilusión, sino efectivo milagro ${ }^{69}$. Una vez más cabe constatar

67 Desde los estudios de M. Griaule y otros se conoce la importancia de la calabaza como símbolo integrante del mito cosmogónico en varias culturas africanas (Dogón, Yoruba); cf. G. Camale-Griaule y V. Gorog-Karady, "La calebasse et le fouet: le thème des objets magiques en Afriques sudsaharienne', pp. 277-313. Tiene funciones análogas en mitologías y folklores del Asia del sur y del este, en zonas de cultura marítima, cf. C. OUwEHAND, Namazu-e and their themes, E. J. Brill, Leiden, 1964 (sobre la importancia del hyotan o cantimplora concebida como receptáculo-matriz de la fuerza divina en el folklore japonés); J. Przyluski, "Un ancien peuple du Penhab: les Udumbara", JA, 1926, pp. 29 ss. (sobre "le mythe austroasiatique de la courgeancetre"' y sus transposiciones legendarias). M. ELIADE, Traité d'histoire des religions, Paris, 1949, pp. 259 ss., pasa revista rápidamente a estos mitos reduciéndolos al tema de la "descendance mythique à partir d'une espèce végétale", lo que me parece demasiado simplificador. Resulta también probablemente equivocado considerar este tema mítico como puramente marítimo: los trabajos de F. D. K. Bosch, A. K. Coomaraswamy, F. B. J. Kuiper y W. D. O'Flaherty han puesto de manifiesto los orígenes védicos de los motivos del "huevo de oro" o de la "tinaja de las aguas primordiales" (cf. KuIPER, op. cit., pp. 144-146, y Ancient Indian Cosmogony, New Delhi, 1983, passim).

${ }^{68}$ Sobre las alusiones sexuales y la significación cosmogónica del rompimiento de la calabaza véanse G. CALAme-Griaule, "La calebasse brisée", Cahiers de Littérature Orale, 1 (1976), pp. 23-66; D. Paulme, op. cit., pp. 282-284 y 311 , y F. B. J. KuiPer, op. cit., pp. 162-165.

69 Cf. Paulme, op. cit., p. 234 (dos potrancas salen de la calabaza) y p. 283. En un cuento bulú, como en nuestra historia del tonto y del huevo de yegua, se le escapa la calabaza a la heroína, y va rodando sin detenerse haciendo recorrer a su perseguidora una trayectoria que corresponde a un viaje iniciático, quizás repetición mímica de! correr de los astros: el cuento catalán 
que las historias de locos se construyen por trasposición y contraposición: imágenes y secuencias sacadas de un antiguo repertorio mítico son recuperadas y adaptadas, invertidas en otros esquemas narrativos que corresponden a nuevas mentalidades (una marcada oposición separa lo posible y lo imposible, la mentira y la verdad, la ilusión y la realidad). Sin embargo, queda en pie el primitivo vínculo entre la ingenuidad absoluta - que ahora se interpreta peyorativamente como locura o tontería- y los orígenes del mundo y de la vida ${ }^{70}$.

6. Este entronque tradicional del loco o bobo con las fuerzas generativas y primordiales del universo, simbolizadas por el huevo o la calabaza, muestra que dicho personaje es lejano descendiente de figuras míticas del Primer Hombre o del Héroe Civilizador, heredero venido a menos, por cierto: al hacer de él un subnormal o un subalterno más o menos grotesco e infantil, los nuevos sistemas de valores y representaciones que lo reconstruyen ponen en entredicho su virilidad al mismo tiempo que sus aptitudes mentales. Su relación originaria con un poder generativo, por ser femenino (o femenino por ser generativo) se va desvalorizando según se establece y endurece el pensamiento falocéntrico: así se constituyó la figura del tonto como persona sexualmente incapacitada o invertida. Su bisexualidad nativa y su conciencia espontánea de una fuerza germinativa difusa en to-

ha conservado la imagen de esta carrera eterna, ya que los tres fadrins "van creure que era la somera que havia sortit de l'ou i arrencaren a córrer al seu darrera per veure si l'atrapaven... i corre que correras, i de segur que si no s'han aturat encara deuen córrer ara" (AMADEs, op. cit., p. 908). Veremos también que el hombre parido corre tras su progenitura.

${ }^{70}$ La función del héroe primordial es a la vez destructiva, ya que rompe la calabaza (o mata al dragón, que es otra forma de la Entidad Cosmogónica), y positiva, porque este destrozo da nacimiento al cosmos organizado al liberar los bienes y seres encerrados en el receptáculo primitivo. En los cuentos occidentales aparecen opciones contradictorias en cuanto al comportamiento del tonto: algunas veces resulta positivo (sin dejar de ser un tonto encuentra tesoros o accede al poder), otras veces se insiste en su aspecto negativo y destructor (FABRE y LACROIX, op. cit., núm. 43: el tonto mata a su burra porque no quiere empollar los “huevos"). - Obsérvese que en la misma versión, como en otras de la misma región, aparece el motivo del capacho, en el que el tonto transporta el "huevo": generalmente éste se escapa cuando el tonto deposita el capacho en el suelo. Un episodio análogo se encuentra en muchas leyendas topográficas que son al mismo tiempo mitos de fundación: un gigante - Gargantúa o el Diablo- da configuración al paisaje dejando escapar objetos que lleva en un cesto, cf: H. DonTenville, "Géographie de Gargantua", en Histoire et géographie mythiques de la France, Paris, 1973, cap. 8. 
da la naturaleza, anterior a toda diferenciación sexual, ya no son consideradas sino manifestaciones de un subdesarrollo personal o de una inadaptación ${ }^{71}$. Al mismo tiempo se va dando una nueva interpretación, reduciéndolo a una significación restringida, al juego agónico que suscita el amor mediante la lucha de los $\operatorname{sexos}^{72}$.

Así se plasma el ciclo de cuentos que presentan al tonto esencialmente como individuo ignorante de las cosas del sexo: inferioridad más manifiesta aún cuando se le imagina casado con una mujer lista y autoritaria que, por "llevar los calzones", va feminizando o incapacitando a su débil esposo. En estos relatos, toda la carrera amorosa y matrimonial del tonto lo define como protagonista exterior o inferior a la supuesta norma sexual: su inaptitud o ignorancia se pone de relieve en cuentos tan conocidos como el del muchacho que nunca ha visto a una mujer ${ }^{73}$, en la serie de anécdotas relativas al disparatado cortejo del novio idiota ${ }^{74}$, o al intercambio de tareas masculinas y femeninas en un matrimonio campesino ${ }^{75}$. En algunas versiones de este tipo de cuento, la inversión de ocupaciones y menesteres lleva al marido a un afeminamiento que a veces se resuelve en verdadera castración: tratando en vano de cumplir con las tareas hogareñas - mientras que su mujer está trabajando en el campo-, el marido provoca una serie de catástrofes. La última de las cuales es permitir que un animal (una yegua, en la versión rusa ${ }^{76}$ ) le muerda y seccione los

${ }^{71}$ La hipersexualidad (que es también bi- y polisexualidad) de los "Tricksters" o "Décepteurs" de varias mitologías y de los "payasos rituales" que los encarnan, así como su ambigüedad constitutiva (ya que se le suele atribuir frecuentemente transformismo y amovilidad de los atributos genitales), desaparecen y no se retiene más que una afeminación o una importancia unívoca.

72 D. PAulme, op. cit., p. 311, destaca, en el ciclo relativo a la calabaza como "madre devoradora", los elementos de un conflicto que opone "principe masculin" y "féminité insatiable" y la representación de "l'instauration d'un ordre viril qui succède au chaos".

73 Aa-Th. 1678 ("The boy who had never seen a woman"). Véase también el tipo 1686 ("Numskull believes he is married to a man").

${ }^{74}$ Aa-Th. 1685 ("The foolish bridegroom"). Véase FABRE y LACROIX, op. cit., núm. 56 ("En Jan Golut"): el héroe desconoce la antomía femenina y proyecta simbólicamente la angustia de la castración al poner sus dos manos en un cántaro donde quedan cautivas. Su desarrollo psíquico parece haberse parado en un estado oral-anal, ya que sólo le interesa comer y se da una identificación final del alimento con excrementos. Nótese que el motivo del cántaro roto reaparece aquí, pero invertido: ya no significa coito o creación cósmica, sino final desastroso de un cortejo fracasado.

$75 \mathrm{Aa}-\mathrm{Th} .1408$ ("The man who does his wife's work").

${ }^{76}$ Contes secrets russes, Paris, 1981, pp. 60 ss., núm. 27 ("Le paysan qui 
genitales. La mujer, a la inversa, va acaparando la hombría que falta a su marido y lo obliga a empollar huevos: en este caso no se trata de una locura espontánea, sino de una humillación o de un escarmiento deliberadamente impuesto al hombre por la mujer ${ }^{77}$. Muy significativa es la versión rusa en la que la esposa del campesino perezoso y clueco se viste de soldado y viene a castigarle a latigazos: en el episodio se aprecia claramente la total inocencia sexual del palurdo, ya que la disfrazada mujer le muestra el propio sexo haciéndole creer que es una herida de guerra ${ }^{78}$.

\section{EL HOMBRE PREÑADO: MITOS, CREENCIAS Y PATRAÑAS}

La misma degradación de un tema mítico en imagen burlesca y satírica se puede observar cuando se considera la evolución de las figuraciones del embarazo masculino: otra vez se advierte la persistencia de la misma relación entre locura y nacimiento.

Al concepto de "loco-clueco" o loco ponedor - ya presente en el repertorio icónico de la Compagnie de la "Mére Folle" de Dijon ${ }^{79}$ - corresponde simétricamente el del parto (cesáreo) de

fait le besogne de sa femme"). Esta colección anónima es una reedición de la traducción francesa de cuentos rusos recogidos por AfANAISEF, en Kryptadia. Recueil de documents pour servir a l'étude des traditions 'populaires, I. Heilbronn, 1883. En la versión catalana (J. Amades, Folklore..., pp. 1061 ss., núm 440, "En Galdric i la Galdrica'), los protagonistas son sólo novios: En Galdric destroza los huevos de la gallina a bastonazos para ayudar a los polluelos a salir del cascarón. El episodio final de la castración no se menciona sino de forma meramente alusiva: el tonto está desnudo y le muerde el ganso (sin mayor precisión). Sobre el ciclo de cuentos relativos al "foolish man and his wife", véanse tipos 1405 a 1429 .

${ }^{77}$ En el ciclo de "la mujer mandona" (Espinosa, op. cit., núms. 91-92), es el marido el que al final sale ganando, ya que consigue domar al marimacho (cf. Aa-Th. 670 y 900-904, toda una serie de tipos y subtipos reunidos en un ciclo general titulado "The shrewish wife is reformed"), pero en algunas versiones la mujer le impone su voluntad al esposo (en A. M. EspinosA, op. cit., t. 2, p. 355: el apaleado marido ". . .llega a sacar pollos de unos huevos que su mujer le ha metido entre los trapos"; el mismo tema será tratado por Maupassant en Toine).

${ }^{78}$ Contes secrets russes, pp. 53 ss., núm. 24 ("Le mari qui couve”). El motivo del idiota al que una mujer hace creer que su sexo es una herida no ha sido debidamente catalogado ni estudiado: es antiquísimo (se encuentra ya en un episodio de Margites, epopeya cómica griega que se atribuyó a Homero, cf. A. B. Pajares, ed., Fragmentos de épica griega arcaica, Madrid, 1979, pp. 386-397) y de extensa difusión (figura en la leyenda india del ermitaño-unicornio Rsyaśrnga, cf. W. D. O'FlaHERTY, op. cit., p. 301).

${ }^{79}$ E1 bastón de la "Mère Folle" representa en el siglo Xv un grupo de 
los locos en la literatura carnavalesca del Renacimiento alemán ${ }^{80}$. El motivo tiene un claro carácter festivo y simbólico (como dice el refrán, "un loco hace ciento"). Pero cabe preguntarse si no vehicula en ciertos casos intenciones más precisas y representaciones más profundas. R. Zapperi ha dedicado al tema un libro de gran erudición y penetración, destacando en particular el trasfondo polémico de toda una serie de cuentos y documentos iconográficos: después de que el cristianismo medieval trató de imponer, a través de la remodelación del episodio del nacimiento de Eva (que viene a ser hija de Adán, parida directamente por él), el dogma feudal de la supremacía del padre sobre los hijos, del hombre sobre la mujer y de los señores sobre los súbditos, la cultura folklórica reaccionó invirtiendo el sentido del mensaje y volviéndolo en contra de los representantes del sistema opresor (amos y sacerdotes), ridiculizados en su deseo e intento de presentarse a la vez como padres - ya que no renuncian, ni mucho menos, al falocentrismo- y madres de sus subalternos ${ }^{81}$. La demostración es brillante, pero sólo se centra en su aspecto parcial de las tradiciones movilizadas, puesto que hace caso omiso de los elementos de la cultura folklórica que se determinan independientemente de la cultura dominante, en particular de los elementos rituales ${ }^{82}$, y no considera sino los componentes burlescos, satíricos y negativos del tema.

Cabe subrayar, en efecto, que éste no se inscribe en la "cul-

"locos" que salen de un nido (reproducción en C. GAIGNEBET, Le folklore obscène..., p. 161).

80 Véase el grabado que ilustra el Fastnachtspiel del "Parto cesáreo de los locos" (Das Narrenschneiden): un loco al que le acaban de abrir el vientre con un cuchillo da a luz toda una prole de incipientes parecidos a él, vestidos con trajes de bufón (grabado reproducido en el catálogo de la exposición Die Welt des Hans Sachs, Nuremberg, 1976, núm. 271, p. 247).

${ }^{81}$ Sigo la traducción francesa, más completa que el original italiano: L'homme enceint. L'homme, la femme et le pouvoir, Paris, 1983. Zapperi muestra también que en el Renacimiento la cultura burguesa recupera el mensaje feudal y adopta, en forma laica y urbana, el repertorio satírico destinado a ilustrar y justificar la sumisión de mujeres y campesinos.

$82 \mathrm{El}$ conflicto entre los sexos no es sólo producto de la estrategia de poder adoptada por las clases e ideologías dominantes y de las respuestas que provoca. Hemos visto que ya existe, como antagonismo lúdico y ritualizado, en la propia cultura folklórica, donde desempeña un papel de pedagogía erótica y de actualización de un sistema social exogámico y dualista (cf. M. Granet, Fétes et chansons anciennes de la Chine, Libraire Ernest Leroux, Paris, 1919, y el detenido estudio de los agones griegos que lleva a cabo F. RodríGuEz AdRados en Orígenes de la lírica griega, Madrid, 1976; y Fiesta, comedia y tragedia, Barcelona, 1972). 
tura popular' únicamente como repercusión de una propaganda clerical: tiene raíces "autóctonas", y la figura del hombre preñado no es tan sólo objeto de irrisión o desprecio, pues entraña reminiscencias y connotaciones míticas que a veces le confieren una dimensión noble, e incluso trágica; tampoco es siempre una ficción deliberadamente disparatada, sino que expresa, en contados casos, una creencia efectiva, más propia de la leyenda o del mito que del cuento o de la fábula ${ }^{83}$.

1. R. Zapperi no deja de señalar que en los cuentos folklóricos muchas veces el personaje ridiculizado por la supuesta preñez es un sacerdote: lo explica por la focalización de la agresividad popular contra dicho representante del orden dominante, símbolo de la represión sexual y divulgador de una ideología castradora. Pero no es menos cierto que, por su presunta continencia y por el contacto que mantiene con lo sagrado, el sacerdote (o el monje) hereda ciertas características propias de personajes míticos y rituales. La sexualidad ambivalente de estos personajes les permite desempeñar el papel de mediadores y transformadores, controlar las relaciones entre naturaleza y cultura, caos y cosmos, esfera sagrada y mundo profano, y por lo tanto manipular las fuerzas de la fertilidad y la fecundidad". En muchas culturas "primitivas" el personaje mitológico del Trickster o Décepteur aparece como una especie de demiurgo o héroe civilizador (aunque a veces se le presenta sólo como un fripon divin o proto-loco que no origina más que catástrofes o desajustes). En varios casos es bisexual: se disfraza de mujer, se casa con un hombre e incluso alumbra ${ }^{85}$.

El tema del hombre preñado ocupa también un área importante en las dos Américas: incluye el motivo del hombre que se fecunda a sí mismo (hundiéndose el pene en el codo) y pare. Generalmente el héroe de este ciclo es el "buscador de nidos", niño

${ }^{83}$ Creencia aún debatida por los hombres de ciencia del siglo XviII (cf. P. Darmon, Le mythe de la procréation à l'âge baroque, Eds. du Seuil, Paris, 1977).

84 Tanto como un impotente o un posible afeminado u homosexual, el eclesiástico es presentado muchas veces en la Edad Media como agente hiperfecundante (cf. las creencias relativas al poder genético de la sombra de los conventos, y el simbolismo fálico encarnado en el "moine bourru", estudiado extensamente por W. Deonna).

${ }^{85}$ L. LeVI MaKarius, Le sacré et la violation des interdits, Paris, 1974, p. 226, cap. 5, "Le trickster", respecto a Wakdjunkaga, el trickster Winnebago, que tiene una vulva postiza; y S. Thompson, The folktale, The Dryden Press, New York, 1946, pp. 319 ss., "The trickster cycle", p. 326. 
oculto nacido analmente que hace de término medio entre categorías conceptuales opuestas del mito ${ }^{86}$.

En África, el décepteur es más bien encarnación de la metis, y tiene significación social más que cosmogónica: personaje débil, pero astuto, consigue triunfar sobre los potentes, pero a veces se excede y comete transgresiones o trata de imitar proezas ajenas y fracasa. Esto ocurre, por ejemplo, cuando Araña, después de una riña doméstica, decide procrear a un niño por sí solo: bebe una medicina que le infla la barriga. Quiere dar a luz, pero el vientre se le revienta, y muere ${ }^{87}$. En estas narraciones se admite la existencia de una ley física y orgánica que la magia no puede transgredir: el mito se transforma en cuento "realista" (a lo $f a$ bliau), y la preñez masculina se considera pura ficción, artimaña de astutos o ilusión de tontos ${ }^{88}$.

Los vivos correspondientes de estas proyecciones mitológicas son los tradicionales especialistas de la mediación entre mundo "natural" y fuerzas ocultas: brujos, "payasos rituales" y chamanes, peritos en transgresión controlada y en manipulación de sustancias y objetos sagrados o peligrosos. La iniciación y la carrera del chamán incluyen muchas veces la reversibilidad sexual ${ }^{89}$ y la teórica facultad de dar a luz ${ }^{90}$.

2. Estos ejemplos son exóticos y no pueden tener relaciones

${ }^{86}$ C. Levi-Strauss, L'homme nu, Plon, Paris, 1971, pp. 33-40; véase también pp. 339 ss..

87 D. PAulme, op. cit., pp. 240-241. (El personaje del "Niño astuto" de la fábula africana del "Macho preñado", al que aludimos en la primera parte de este trabajo, es un equivalente del "décepteur" mitológico.) Véanse también Paulme, "Le peronnage du Décepteur en Afrique Noire", La statue du commandeur. Essais d'ethnologie, Paris, 1984, pp. 19 ss.; "Typologie des contes africains de Décepteur", Cahiers d'Etudes Africaines, 60 (1975), y "L'initiation impossible dans les contes du Décepteur africain", Research in African Literatu$r e, 8$ (1977).

${ }^{88}$ A veces coexisten en el mismo relato la denuncia del aspecto ficticio del tema y la creencia en el nacimiento extraordinario: el niño astuto que practica la reductio ad ahsurdum mediante la mención del embarazo de su padre, nació en algunas versiones de un modo antinatural (cf. D. PAULME, La mère dévorante, pp. 199-200, 211-212 y 236).

89 Ya hemos aludido a Tiresias. Sobre posturas de travestismo, afeminamiento e inversión en las diversas formas de chamanismo, véase M. EliadE, Le chamanise, Paris, 1974. Véanse también G. Hamonic, op. cit.; y W. R. HALLYDAY, "A note on the OHAEA NOY $\mathrm{OO} \Sigma$ of the Skythians", The annual of the British School at Athens, 17 (1910-11).

90 C. Levi-Strauss, Anthropologie structurale, t. 1, Pion, Paris, 1958, cap. 12 , "Structure et dialectique" (tema del niño embarazado en una serie de mitos americanos sobre el origen de los poderes chamánicos). 
directas con las tradiciones folklóricas occidentales que estudiamos. Pero en el mundo indo-europeo también floreció el tema desde la antigüedad. En la India conoció un desarrollo mitológico especial, y son manifiestas su relación con las concepciones cosmogónicas (el primer "Hombre preñado" es Prajapati, el dios creador, que produce todo el universo a partir de su propia sustancia $)^{91}$, su importancia en la religión ${ }^{92}$ y sus incidencias rituales ${ }^{93}$. Pero también se suele asociar a personas reales como los yoguis $^{94}$, o a figuras histórico-legendarias como ciertos reyes ${ }^{95}$. Contadas veces tiene matiz burlesco o satírico y en ciertas ocasiones cobra una dimensión trágica, como ocurre cuando se debe inclinar la fantasía ante el determinismo fisiológico real ${ }^{96}$. En relatos mitológicos y folklóricos corrientes en otros sectores de cultura indoeuropea aparece también el hombre preñado, con un tinte cómico (en el caso de Loki, el trickster de la mitología escandina$\mathrm{va}^{97}$ ), heroico ${ }^{98}$, o propiamente teológico ${ }^{99}$.

91 W. D. O'Flaherty, op. cit., pp. 26 y 311.

92 Varios dioses, como Agni y Vishnu comparten el carácter andrógino del Ente Primordial y conocen el parto masculino (ibid., pp. 49-50 y 320-321). En el movimiento de la Bhakti, la relación amorosa e iniciática que une al dios con el devoto se proyecta en la imagen de un dios que traga al hombre que lo adora, lo recoge en su seno y lo vomita o pare (ibid., p. 268; compárese con el tema de la absorción por un dragón en los relatos iniciáticos: el regressus ad uterum precede a un renacimiento).

93 La relación del discípulo y del guru transforma a éste en padre y madre de aquél, ya que simbólicamente lo lleva tres días en su vientre y le da nuevo nacimiento. (Es el significado de la ceremonia upanayama: M. EliAdE, Naissances mystiques, pp. 113 ss.) Este concepto es la base de la famosa leyenda de Kaca y Kavya Uśanas: al parir a su alumno, del que está embarazado por haber tragado sus cenizas, el maestro le enseña el secreto de la resurrección (G. Dumézil, Mythe et épopée, Galllimard, Paris, 1971, t. 2, pp. 160-166, 197-205 у 206-208).

94 W. D. O'Flaherty, op. cit., p. 44 (la retención del semen permite al yogui transformarse en hombre embarazado), cf. pp. 226-227, la leyenda del asceta Urva.

95 Ibid., p. 50: leyenda del rey Yuvanāśva.

96 Ibid., pp. 299-300 (historia del Vidyādhari que muere de parto). Todavía hoy se muestra en Ajmer, Rajastán, la tumba del hijra, o sea, prostituto eunuco y disfrazado de mujer, que quiso parir, comió el fruto de un árbol sagrado fertilizador, y murió por no poder dar a luz (G. Busquet y C. BeAUNE, Les hermafrodites, Paris, 1978, pp. 215-217).

97 Cf. G. DumÉzIL, Loki, Paris, 1948. El autor está preparando una nueva edición revisada y muy aumentada.

98 G. DUMÉzIL, “Les énarées scythiques et la grossese du Narte Xaemyc", Lat, 5 (1946), y Romans de Scythie et d'alentour, Paris, 1978, caps. 13 y 14. Secundado por J. Grisward, el autor compara la leyenda antigua de 
3. En todos estos casos, se deba el embarazo masculino a absorción, autofecundación, transferencia de germen o a transformación provisional en mujer, se trata de un fenómeno considerado "real": la transgresión de la ley natural no plantea ningún problema. Es de señalar que esto no ocurre solamente en mitos, sino también en cuentos, leyendas y probablemente creencias populares más recientes. En el cuento tipo 705 ("Born from a fish") 100, muy difundido en el norte de Europa, un hombre queda embarazado por haber comido un pez mágico destinado a su esposa: le sale una niña de la rodilla. El embarazo por absorción de una semilla o de un fruto maravilloso es motivo harto frecuente en el folklore: se puede dar tanto en hombres como en mujeres ${ }^{101}$. Por último, cabe subrayar que, junto a todas las historias burlescas de pseudo embarazo recopiladas por Zapperi, existe a lo menos una en que se cuenta un parto presentado como efectivo ${ }^{102}$.

También se debe reparar en la ambivalencia del tema y en su relación privilegiada con la realeza. Si el parto masculino es propio de dioses, héroes y figuras eminentemente positivas, también lo es de entidades demoniacas: ya hemos aludido a los huevos del Diablo y al nacimiento del Anticristo. Del mismo modo, se sabe que Loki es un figura escatológica y desempeña un papel esencial en el desencadenamiento final de las fuerzas del mal, y que el loco medieval tiene a veces connotaciones satánicas. Esta valoración negativa del tema culmina con su asociación a la leyenda cristiana de Nerón - ampliamente difundida por la Leyen-

los Enareos, adivinos escitas afeminados, antepasados de los chamanes siberianos y americanos, la del nacimiento de Batraz en el folklore narrativo oseta (su madre "transmite" el germen a su padre, que le dará a luz por parto cesáreo) y el famoso ciclo irlandés de la "Novena de los Ulatas" (guerreros afligidos ocasionalmente por una debilidad análoga a la de la puérpera). En los tres casos se alude a las consecuencias de la maldición echada por una diosa ofendida.

${ }^{99}$ Cf. Dionisos y Atenea paridos por Zeus. Nótese que, en el segundo caso, el tema del embarazo masculino se relaciona, como en África, con la adquisición de la metis.

100 Motivos T 578 ("Pregnant man") y H 791 ("Riddle: A fish was my father, a man was my mother..."). En la versión esquimal una vieja hace posible el parto gracias a un sortilegio (H. RiNK, Tales and traditions of the $E_{s-}$ kimo, London, 1875, p. 443, núm. 94).

101 M. ElIADE, "La mandragore et les mythes de la naissance miraculeuse', Zalmoxis, 3 (1940-42), pp. 35-36.

102 R. ZAPPERI, op. cit., pp. 48-49 (versión recogida por Pitré): obsérvese que el famoso "hombre encinta de Monreale" dio lugar a ambas interpretaciones (embarazo fingido y auténtico). 
da Dorada-, según la cual el malvado emperador quedó preñado de una diminuta rana que le hicieron tragar los médicos y que expulsó por la boca ${ }^{103}$. En casi todos estos casos subyace un complejo de representaciones relativas a la inversión sexual (complejo especialmente desarrollado por el cristianismo medieval): las prácticas de homosexualidad, por otra parte, son consideradas con frecuencia causas posibles del embarazo masculino ${ }^{104}$. Es significativa la diferencia entre la interpretación india y la cristiana de una misma imagen: Vishnu se transforma en mujer, recibe la simiente de Siva y da a luz, después de haber recuperado su forma masculina; el niño nacido en tan extrañas condiciones es un demonio, pero su estancia en las entrañas del dios le confiere estatuto divino ${ }^{105}$. Los teólogos medievales, en cambio, imaginaron que los diablos, para multiplicarse, se transformaban en súcubos femeninos a fin de recoger el esperma masculino y, después, en íncubos a fin de fecundar con él a las brujas: sus retoños serán como ellos, criaturas demoniacas, aunque formados a partir de simiente humana ${ }^{106}$.

Es evidente que la figura cristiana del demonio, como la del "loco", se ha construido por recuperación y reinterpretación unilateral de muchos elementos folklóricos análogos a los que se condensaban en personajes tan polifacéticos como el trickster. de antiguas y exóticas mitologías: pero en el mundo indoeuropeo las entidades míticas de esta clase han quedado marginalizadas, subordinadas o completamente anuladas, y es el rey el mediador privilegiado, el representante por antonomasia del héroe civilizador o del primigenio demiurgo. G. Dumézil y otros comparativistas han

103 A. GRAF, Roma nella memoria e nelle immaginazioni del Medio Evo, Torino, 1882, t. 1, pp. 338 ss.; R. ZAPPERI, op. cit., pp. 116 ss. La rana simboliza el mal, y Nerón fue identificado con el Anticristo, en gran parte a causa de sus práticas sodomitas.

${ }^{104}$ En la forma más antigua de la leyenda (c. 700), Nerón sufre una hidropesía consecutiva al libertinaje homosexual. (Respecto a la homosexualidad de los "locos" y del Anticristo, cf. supra, notas 7 y 45.) Véase ZAPPERI, op. cit., pp. 125 ss., y 190 ss. En varias versiones medievales y folklóricas del cuento del hombre preñado aparece la idea de que dicho fenómeno se explica por el equus eroticus (ibid., pp. 162-176; véanse también pp. 96, 100, 101, 115, 131 , etc.).

105 W. D. O'Flaherty, op. cit., pp. 320-323.

106 Cf. ZAPPERI, op. cit., p. 169. En este caso no hay embarazo masculino, ya que el Diablo es por esencia infecundo y no puede, por tanto, dar a luz; pero el complicado proceso implica la misma conjunción de la inversión sexual con una maléfica prole que el mencionado tema de la incubación diabólica. 
evidenciado la relación que une los ritos y leyendas indoeuropeos de la soberanía, a la representación del Primer Hombre o del Dios Primordial ${ }^{107}$. Esta dimensión sagrada de la realeza explica el que la doble facultad de transformismo y procreación, que en tantas culturas se atribuye al trickster (que encarna, en más de una ocasión, un principio de rebelión y oposición a los poderosos), sea acaparado en cambio, en las culturas indoeuropeas, por el rey o por personajes directamente relacionados con el poder y, por tanto, continuadores de Adán (el primer hombre preñado a partir del momento en que se imaginó que Eva nació de su cuerpo, como atinadamente señaló Zapperi) ${ }^{108}$. Si la cultura folklórica entraña y expresa tanta agresividad contra los amos y los sacerdotes, representantes de un orden opresivo, manejando contra ellos el arma de la ridiculización a través del tema del hombre encinta, es porque dicho tema ya formaba parte de la mitología del poder ${ }^{109}$. El primer dios soberano (que es también dios de los soberanos) es un dios ligador que detenta el poder de manipular el pneuma y de hacer que se hinchen las barrigas: también los reyes, que en determinados casos deben ser obesos, y cuya enfermedad predilecta y simbólica es la hidropesía, participan de esta facultad de inflación y desinflación ${ }^{110}$; y encarnan a veces en su propia per-

107 G. DumÉzIL, Ouranos, Varuna. Étude de mythologie comparée indo-européenne, Paris, 1934; A. Christensen, "Les types du premier homme et du premier roi dans l'histoire légendaire des Iraniens", Archives Orientales, 14 (1917-1934).

108 Sólo que la demostración de Zapperi podría dejar suponer que este sistema de imágenes es creación del cristianismo medieval y del feudalismo: nos parece evidente que éstos no hicieron más que remodelar un conjunto de representaciones más antiguo que se remonta probablemente a la prehistoria indoeuropea.

${ }^{109}$ ZAPPERI, op. cit., pp. 123-124, interpreta la leyenda del parto de Nerón como una fase de "la lutte que l'Eglise menait contre le folklore": se supone que se trataba de desviar la polémica folklórica orientada contra los sacerdotes, focalizándola contra la figura de Nerón, nuevo chivo expiatorio propuesto a las masas. Me parece más bien que para la Iglesia era un medio de exorcizar los fantasmas de un poder mundano que se excede y pone en peligro la autoridad pontifical: el de los emperadores germánicos que pretenden concentrar, como sus predecesores romanos, el carisma de la realeza sagrada de origen pagano y la hegemonía política, negándose a someterse a la autoridad espiritual. Quieren transgredir la necesaria separación de las funciones como Nerón quiere hacer caso omiso de las diferencias entre los sexos. Por esos se asimilan al Anticristo y paren criaturas diabólicas.

110 G. DumÉziL, Ouranos..., p. 97; Mythes et dieux des germains, P.U.F., Paris, 1939, p. 59; Flamen-Brahman, Paris, 1935, pp. 22 ss. Cf. ZAPPERI, op. cit., p. 119, con respecto a la relación establecida por Benveniste entre "Kueîn" (estar embarazado) y "Kûrios" (soberano). 
sona un doble principio de paternidad y maternidad ${ }^{11}$.

4. La complejidad de estas herencias culturales explica que el tema del hombre preñado, tal como aparece en el occidente cristiano desde la Edad Media, sea encrucijada de tradiciones y no se pueda explicar de modo unitario. Sólo puede cobrar la dimensión polémica que desentraña Zapperi porque lo respalda un trasfondo de representaciones, algunas de las cuales reflejan mentalidades y creencias arcaicas. Antes de ser considerado mero disparate lúdico, tontería de rústicos o símbolo de diabólica locura, antes de haber sido usado por la Iglesia (mediante el motivo del parto de Adán) como instrumento dogmático, y por el folklore como arma satírica contra la ideología y las clases dominantes, fue el centro de un conjunto de pretéritas ideas relativas a la concepción y a la diferenciación sexual.

Se siguió creyendo, por ejemplo, hasta bien entrada la Edad Media, que algunos hombres tenían la regla mensual como las mujeres (idea arcaica ${ }^{112}$ que se solía aplicar a los judíos ${ }^{113}$ ) o leche en los senos con la que podían amamantar ${ }^{114}$ : en la España del Siglo de Oro este tema daba lugar a controversias eruditas ${ }^{115}$ y cuentecillos humorísticos, como el que refiere Luján de Sayavedra en su Guzmán ${ }^{116}$. También casos míticos y reales de herma-

111 D. A. Miller, "Royauté et ambigüité sexuelle. Symbolique de la monarchie a Byzance", AESC, 26 (1971). Ya apuntaba Aristóteles que la enfermedad "femenina" que aquejaba a los Enareos escíticos era enfermedad de reyes (basileis): G. DumÉzIL, Romans de Scythie..., pp. 214 y 217.

${ }^{112}$ Cf. Motivos F 569-2 ("Men menstruate") y A 1355-3 ("Previously men menstruated"), frecuentes en la India y en América, donde se realcionan con el poder mágico atribuido a la sangre menstrual (L. MAKAR IUS, op. cit., pp. 272-273) y el simbolismo de la subincisión (B. BeTtLeHEim, op. cit., pp. 121 ss.).

${ }^{113} \mathrm{~J}$. Le Goff, "Le juif dans les exempla médiévaux: le cas de l'Alphabetum Narrationum", Mélanges L. Poliakov: le racisme, mythes et sciences, Bruxelles, 1981 , p. 216.

${ }^{114}$ W. D. O'Flaherty, op. cit., pp. 21 y 289. En algunas leyendas folklóricas de osos raptores, el animal amamanta a su víctima. La tradición rabínica atribuye a Mardoqueo parecida hazaña. (Cf. G. LEGMan, Psychanalyse de l'humour érotique, Paris, 1968, pp. 449-450.) Algunos bobos, como Xailún, no se contentan con empollar huevos: también quieren amamantar.

${ }^{115}$ JuAN DE PINEDA, op. cit., diálogo XIV, cap. 22.

116 "Un buen hombre, cuya mujer mandaba a más de a medias en casa, estando unos médicos en conversación, escusó una disputa sobre por qué causa la naturaleza criaba leche en los pechos de algunos hombres; porque habiendo respondido uno dellos que la naturaleza no hacía cosa en balde, y que sin duda criaba leche en los pechos de los hombres para algún fin, y a su parecer era para que el hombre a una necesidad pudiera sustentar los hijos con 
froditismo alimentaban la creencia en la posibilidad de que el hombre se transformara en mujer. Historias de este tipo abundan en la India ${ }^{117}$, y aunque siempre suscitaron escepticismo en las especulaciones eruditas occidentales ${ }^{118}$, encontraron favorable acogida en el folklore narrativo ${ }^{119}$.

No es de extrañar, por tanto, que, fuera de todo contexto polémico o intención satírica, se encuentren alusiones a un tema que, antes de ser chistoso, debió de gozar de tanto crédito popular como los incontables "casos" extraordinarios o legendarios relatados en misceláneas renacentistas y en pliegos de cordel: en La Octava Maravilla, Lope de Vega menciona la existencia de una versificada "historia trovada" (que circulaba en papel impreso con letras de molde) "de un hombre que cuando menos / dicen que parió en Granada"'120. En otra ocasión el mismo Fénix se divierte hilvanando el tema, todavía relacionado con "la barbaridad de España", en Las batuecas del Duque de Alba: los rústicos batuecos recogen a una dama (disfrazada de hombre) que acaba de parir y creen que se trata de un hombre preñado. Llegan a imaginar que "los hombres del otro mundo [suelen] parir de siete en siete años", y aducen ejemplos naturales como " ¿El gallo non pone un huevo? / ¿La liebre no es fembra y macho?" " Claro está que con esta anécdota volvemos a la otra vertiente de la patraña, donde imperan el engaño o la ilusión, la sátira de la boba ingenuidad que se atribuye a los labradores.

su leche. Oyéndole nuestro buen hombre dijo desta manera: 'señores, por amor de Dios os ruego habléis paso, que si las mujeres alcanzaran a saber esto, nos harán criar nuestros hijos siempre, y alguna vez los ajenos' ' (Segunda parte, III, 7; $B A E, 3$, p. 419 a.) Debo esta referencia a la erudición y amistad de Michel Moner. Nótese la aviesa alusión a la mujer mandona y adúltera.

117 W. N. BROWN, "Change of sex as a hindu story motif", JAOS, 47

(1927); W. D. O'FlAHERTY, op. cit., pp. 299-309.

${ }^{118} \mathrm{Cf}$. JUAN DE PINEDA, op. cit., diálogo V, cap. 3.

${ }^{119} \mathrm{H}$. Gaidoz, "Du changement de sexe dans les contes celtiques", RHR, 57. Motivo D 12 ("Transformation: Man to Woman").

${ }^{120}$ Sería algún romance de ciego, ya que al escéptico Juan de Arellano (“¿Hombre parir? ¿Quién lo afirma?”) contesta Motril: “Los ciegos, que ven, señor”. Se nota la reprobación de Lope por tal superstición y tan soez literatura, cuando le hace dictaminar a Juan: " ....con esto se confirma/la barbaridad de España... Cosas que hacen mayor daño/del que parece" (Real Academia Española, Madrid, 1930, t. 8, p. 255). M. Moner me recuerda que el episodio es mencionado por J. CARO BAROJA, Ensayo sobre la literatura de cotdel, Revista de Occidente, Madrid, 1968, p. 51.

${ }^{121}$ Real Academia Española, 1900, t. 11, p. 536. 


\section{EL HOMBRE PREÑADO: BURLAS Y VERAS}

Probablemente plasmado en el contexto ritual de las competiciones intersexuales a las que aludía antes, el tema del hombre preñado de la tradición folklórica europea parece haber perdido toda conexión con las ideas cosmogónicas e iniciáticas ya mencionadas: en la inmensa mayoría de los casos es pretexto de burlas, ya que, como broma o engaño, se le atribuye a un tonto la certeza de que está embarazado: se opone el mundo real al de la ilusión y se hace befa de la credulidad del ignorante rústico (perspectiva "aristocrática") o de las obsesiones y locas aprensiones del poderoso engañado por las artimañas de sus astutos súbditos (perspectiva "folklórica" o antiaristocrática, según la terminología de Zapperi a cuya excelente recopilación de textos remito).

1. Los tipos más difundidos son dos, y ambos pueden emplearse en una y otra perspectiva.

En el primero y más conocido, un enfermo manda una botella llena de su orina a un médico para que la examine. Antes de llegar a su destino, por accidente (se rompe la botella) o acto intencional, la orina es sustituida por la de una mujer o una vaca preñada. El doctor diagnostica el embarazo. Al enterarse de la noticia, el enfermo se prepara con vista al esperado parto o, avergonzado, trata de conseguir, de un modo más o menos violento, un aborto. El trance se concluye generalmente con la aparición inopinada (y huida inmediata) de un animal - liebre o zorroque pasaba por el lugar de la operación o estaba oculto en un matorral vecino. El tonto cree que el animal es su hijo: a veces trata vanamente de perseguirlo para bautizarlo ${ }^{122}$. Es frecuente que toda la aventura no sea más que una burla urdida por un chistoso o vengativo protagonista deseoso de engañar al crédulo paciente ${ }^{123}$.

122 Aa-Th. 1739 ("The parson and the calf"), Motivo J 2321 ("Man made to believe that he is pregnant"). En algunas versiones no aparece el episodio de la sustitución de orines: el hombre cree que ha parido porque, al despertar, encuentra un animal - ternero, gatito, etc. - cerca de su cama. En otros casos, después de una comilona, el desgraciado suelta un pedo formidable: asoma entonces inopinadamente (o le presentan deliberadamente) una criatura que él cree nacida de su ventosidad. Es el tema del conocido cuento del cadí avariento de las Mil y una noches. (Véanse Chauvin, op. cit., núm. 107, t. 5, pp. 184-185; ZAPPERI, op. cit., pp. 217 ss.)

${ }^{123}$ Cf. Boccaccio, Decamerone, IX, 3 (cf. ZAPPERI, op. cit., pp. 153 ss.; A. C. LeE, The "Decameron": Its sources and analogues, London, 1909, pp. 277 ss.) 
El segundo tipo se mezcla a veces con el primero, incluyendo, sin embargo, un elemento original: un animal o un objeto cualquiera se ha introducido (por la boca o por el ano) en el cuerpo de un hombre sin que éste se percate del hecho. Le crece el vientre y sufre dolores insólitos, hasta llegar a creer, espontáneamente o influido por sugerencias maliciosas de algún allegado, que está embarazado. A veces, ayudado por un potingue o una lavativa, expulsa analmente el elemento extraño, creyendo que se trata de un parto auténtico ${ }^{124}$

En estos casos, el embarazo y el parto son a la vez imaginarios y efectivos, siendo reales sólo la absorción y la expulsión, aunque de interpretación disparatada. En ambos tipos cabe distinguir versiones que implican un engaño deliberado y versiones en que la creencia del protagonista en la realidad de su preñez es espontánea, y no se debe a sugerencias ajenas, sino que es fruto exclusivo de la propia fantasía.

Se puede considerar como tipo aparte el cuento renacentista en que el embarazo masculino es simulado por un marido que quiere engañar a su esposa haciéndole creer que se encuentra en dicho estado por haber practicado con ella el equus eroticus: con la complicidad de un médico que alucina fácilmente a la crédula mujer diciéndole que se puede transferir el embarazo a otra persona, se las arregla para que la misma esposa le suplique se acueste con la criada (que es quien en realidad está encinta por obra de su amo) para salvar la honra familiar al comunicarle el germen colocado en indebido lugar. Consigue así el marido adúltero continuar sin trabas con sus amores ancilares, y justificar los resultados de su relación clandestina sin alterar la paz conyugal ni la reputación de la casa ${ }^{125}$.

124 Cf. Fabre y Lacrolx, op. cit., núm. 65 ("En Jan encent"): se trata, otra vez, de un hombre muy goloso que se traga un copo de lana mezclado con sus alimentos, sin darse cuenta de ello. "El ventre se gonfla" y cuando Jan va a "parir" cerca de un matorral, suelta "un pet terrible" que espanta a una liebre y Jan "pensava d'aver fet le mainatge". - La más antigua de las versiones conocidas figura en una colección de fábulas esópicas, Romulus (s. IX): "El ladrón y el escarabajo" (cfi ZAPPERI, op. cit., pp. 71-72 y 54-55, una versión siciliana moderna: en ambos casos el insecto se introduce en el vientre del protagonista por la vía anal). Véase S. Lo Nigro, op. cit., núm. 1739 ("Il prete pregno").

125 ZAPPERI, op. cit., pp. 196 ss. Esta supuesta posibilidad de transferencia del embarazo me parece una parodia de las creencias en las alternancias sexuales del diablo como íncubo y súcubo. El papel del tonto lo desempeña en adelante la mujer. 
2. La contraposición recalcada por Zapperi entre versiones folklóricas y antifolklóricas, interpretadas las primeras como sátiras contra los ignorantes campesinos, y las segundas como reacción de los mismos contra sus detractores (binomio que sirve de matriz para toda una serie de oposiciones secundarias: ciudad vs. campo, marido vs. mujer etc.), sólo es valedera en contextos conflictivos y no puede considerarse originaria: el cuento bien puede ser instrumento de lucha, pero es ante todo expresión de una cultura, y la consabida teoría de la oposición entre "cultura popular" y cultura oficial, o erudita, no agota todos los fenómenos de transferencia y aculturación que dan su sello especial a las sociedades occidentales del Medioevo tardío y del Renacimiento ${ }^{126}$. Es cierto que, en determinados medios, se quiso indentificar al labrador o "villano" con el loco, entendiéndose este término más en el sentido de una bobería absoluta que en el de demencia o desarreglo psicológico, y no menos cierto es que en España, en particular, esta identificación fue objeto de una acusada elaboración literaria y dramática ${ }^{127}$.

Resulta interesante, por lo tanto, constatar que, en ninguna de las tres versiones hispánicas que conozco, se hace mención precisa de la implícita condición campesina de los principales protagonistas del cuento (siempre se trata de "un hombre", "tres individuos"...), y que no se da ni el menor asomo de sátira contra los rústicos ${ }^{128}$. Pero tampoco se puede decir que sirva el tema para expresar disposiciones revanchistas hacia los privilegiados o hacia los que ocupan una situación dominante: no aparecen sacerdotes ni monjes, y si el hombre preñado es amo en el cuento albercano (tiene un criado al que le confía los meados que hay que someter a examen médico), y padre de familia en la versión americana (es su hijo quien, a instancias de la madre, se hace cargo del recado), su ridiculización no acarrea ninguna compensación

${ }^{126}$ El término de "cultura folklórica" no es menos equívoco, ya que a veces también se habla de "folklore" aristocrático e incluso monárquico.

127 Ibid., p. 109 y N. Salomon, op. cit., passim, Primera parte.

${ }^{128}$ Una postura contraria resultaría asombrosa, ya que son relatos de tradición oral recogidos en medios campesinos: L. CorTes Vázquez, Cuentos populares salmantinos, Librería Cervantes, Salamanca, 1979, t. 1, pp. 109-110, núm. 50, "El tío preñao" (recogido en La Alberca); J. Camarena LaUciriCA, Cuentos tradicionales recopilados en la provincia de Ciudad Real, t. 2, Instituto de Estudios Manchegos, Ciudad Real (en preparación): "El tonto que quería parir', recogido en Piedrabuena en 1980, cuyo texto me comunicó por anticipado el autor; J. B. RAEL, op. cit., t. 2, pp. 360 ss., núm. 237, "El preñado de ternera" (Colorado). 
o satisfacción a los que de él dependen. No hay burlador ni burlado, y los que practican la sustitución de orines son incluso más tontos y ridículos que el "preñado": en ambas ocasiones, creyendo que es vino, beben el contenido del recipiente antes de volver a llenarlo...

En cambio, en la versión de Piedrabuena, que es algo distinta por no incluir el episodio de la sustitución de orines, se trata de una auténtica burla de la que los listos hacen víctima a un compañero "un poco falto", dándole potingues y haciéndole creer que está embarazado: luego le asisten en el "parto", provocando dolores artificiales en la parte posterior del paciente con un raspón de besugo, y le muestran el lagarto que se supone él acaba de dar a luz. Pero la burla no entraña ningún antagonismo socio-cultural: no aparece otro binomio que el de listos vs. tontos en su forma más abstracta ${ }^{129}$.

En ninguno de estos cuentos se trae a colación un tema conílictivo como el de la supuesta homosexualidad o el de la inversión de posiciones en el coito, que tantas veces se encuentran en otras versiones europeas. En el universo campesino en que se sitúan estos cuentos hay amos y criados, padres e hijos, listos y tontos, pero su espacio cultural común es homogéneo y todos comparten los mismos valores; valores presentados como universales y admitidos tanto por el narrador y su público como por los personajes del relato.

3. Los cuentos hispánicos nos permiten vislumbrar el aspecto fundamental del tema, menos visible en otras versiones occidentales que lo cuelan en esquemas narrativos ajenos e invierten en él preocupaciones socio-culturales muy distintas, vinculadas con otro tipo de mentalidad: la oposición básica en la que estriban las tres versiones no es tontería vs. astucia o dependencia vs. dominación, sino pasividad vs. actividad. Como situación inicial del cuento se da una disposición anímica peculiar del protagonista, estado excepcional (enfermedad) o constitutivo y casi ontológico (rasgo psicológico). Esta disposición, que se presenta como carencia y causa de insatisfacción para el propio protagonista o para sus allegados, es la raíz y condición del desarrollo ulterior del escenario que va a consistir en una operación catártica destinada a acabar con dicha carencia.

La consecuencia inmediata de esta disposición es un estado de torpor o inmovilidad (o deseo de inmovilidad): en el cuento de Colorado se trata de "un hombre que era muy flojo para tra-

129 "Pues eran tres individuos y dos eran más listos que el otro..." 
bajar y se mantenía en la cama muriéndose...' Esta inercia exaspera a su mujer que, al parecer, asume todas las funciones activas y ejerce la autoridad doméstica (manda a los hijos y decide por sí misma consultar al médico ${ }^{130}$ ). Todos los sucesos narrados en el cuento - sustitución de orines, pretendido embarazo, "parto" de la ternera - concluyen con la cura definitiva del preñado: "se fué pa su casa y ya llegó muy trabajador y ya no se quedaba en la cama por no ponerse encinta de ternera". Al "salir de su cuidado" el hombre flojo recobra su vitalidad y energía: la alucinación ya no es burla, sino terapia mental y se inscribe en un proceso de recuperación del juicio y de la virilidad, funcionando como escarmiento provisional. Hay que pasar por la ilusión, asumir completamente la lógica de la propia locura para apurarla y volver a la norma.

En la versión salmantina, el protagonista está tan gordo que no puede "ni montar en caballería, ni andar...", sintiéndose "muy de saguhto". Después del episodio de la sustitución y del examen médico, el enfermo decide provocar un aborto (o acelerar el parto) saltando desde un árbol ${ }^{131}$. Al caer espanta a un gato que huye corriendo, y no consigue retenerlo: “-¡Ven acá! ¡No te vayas sin conocer a tu padre!" Hay una clara oposición entre la inmovilidad del enfermo y la extrema agilidad del fugitivo gato: no se indica en el cuento si el parto libera al protagonista y le permite recuperar el movimiento, pero es probable que se admita implícitamente que la operación, aunque es imaginaria, tiene el mismo efecto catártico que en la versión americana, ya que en una ver-

${ }^{130}$ Así que la contradicción entre inactividad (sexual) y autoridad (social o moral), reunidas en un mismo personaje en la mayoría de las versiones "polémicas" examinadas por Zapperi, queda aquí desplazada y no se plantea ya en los mismos términos: la misma inercia del varón obliga a la mujer a asumir el papel masculino. Hay alteración de un orden considerado natural, que se concreta ante todo en la debida y tradicional repartición de funciones y tareas entre los sexos, y la operación catártica tiende a restablecer este orden cuya legitimidad nunca se pone en tela de juicio, ya que no se lo considera ante todo un sistema de dependencias y dominaciones, sino una balanza innata de elementos opuestos y complementarios. El orden tradicional no puede entranar un aspecto opresivo puesto que es conforme a la naturaleza profunda de las cosas: es orden inmanente, no orden "establecido". Aparece la opresión cuando se invierte o altera. Es de notar que la misma oposición entre hombre inerte y mujer activa y mandona se encuentra en la otra extremidad del área de difusión del tema, en Rusia; es decir, en una sociedad tan marcada por su trasfondo de cultura tradicional campesina como la española (cf. supra, "Le mari qui couve"').

${ }^{131}$ Cf. una técnica análoga en ZAPPERI, op. cit., pp. 55 y 56. 
sión danesa del mismo relato se menciona que el abultado monje Miguel se vuelve flaco después del parto imaginario ${ }^{132}$.

El estado de abulia o torpor que paraliza a los héroes de estos cuentos se parece mucho a la inmovilidad de los ya mencionados cluecos, y se relaciona con toda la tradición folklórica de los "perezosos" (cf. tipos 675 y 822, y el tema de la Tierra de Cucaña, paraíso de los gordinflones y dormilones). Pero también entraña probables reminiscencias de arcaicos fenómenos psicosomáticos - vinculados con ceremonias cíclicas - y el proceso del parto debió de construirse a partir de un repertorio de motivos e imágenes sacado de rituales terapéuticos, parecidos a los que se operan en el tarantulismo o en el exorcismo aplicado a los demoniacos. El paciente es "habitado" por un cuerpo o una fuerza extraña de la que trata de desembarazarse, expulsando lo que cree haber ingerido ${ }^{133}$.

Dos motivos de la versión salmantina revelan este entronque mítico-ritual: la orina del enfermo es recogida en una calabaza, detalle arcaico que el narrador ya no entiende y que trata de justificar torpemente ("...porque allí era cohtumbre el echar el vino en calabazah pa beberlo" $)^{134}$; en cuanto al salto desde lo alto de un árbol, es a la vez tema de ordalía y recuerdo de un acto cosmogónico, la zambullida del earth diver, mito de emergencia, cuya relación con el concepto de parto masculino y anal ha sido ponderada por A. Dundes ${ }^{135}$.

En cuanto a la tercera versión castellana, se especifica en ella que el protagonista "tenía envidia de cuando paría una mujer lo bien que la cuidaban'. Es la única versión en la que el parto no es objeto de vergüenza, aunque sí es efecto de una burla puesta en práctica por los dos compadres astutos que le hacen experi-

132 Ibid., pp. 86-87. Este "milagro" revela la naturaleza psicosomática de la enfermedad y de la terapia. Al revés, en un relato que Zapperi entresaca de un sermón italiano del siglo XVI, un desgraciado al que le hacen creer, en son de broma, que sufre hidropesía, se asusta, se vuelve efectivamente hidrópico y se muere (pp. 153-154).

133 En los tres casos aparece la obsesión de ser "cabalgado" por una entidad parásita (cf. H. Jeanmaire, Dionysos, Payot, Paris, 1970; E. De MartiNO, La terre du remords, Paris, 1966). Esta obsesión reaparece en la explicación de la preñez masculina por la práctica del equus eroticus (ZAPPERI, op. cit., pp. 162 ss.)

${ }^{134}$ Cf. supra nuestros comentarios sobre el simbolismo cosmogónico y sexual de la calabaza (nótese que en muchas versiones del cuento se sustituye la orina porque se ha roto el recipiente).

135 A. Dundes, "Earth-diver: Creation of the mythopoeic male", $A A, 64$ (1962), pp. 1032-1051. 
mentar al compañero "un poco falto" los dolores y alegrías del alumbramiento, dándole potingues, atormentándole el culo con el raspón de besugo y presentándole el lagarto que se supone acaba de parir. Aquí, la oposición principal es: mimos de que es objeto la mujer parida $v s$. trabajos y dolores que sufre la parturienta. El narrador insiste mucho en el contraste entre la realidad del sufrimiento y lo fingido del parto (en otras versiones son los dolores ocasionados por los intentos de aborto: bastonazos, caídas etc.), y llega a imitar los gritos del desgraciado ${ }^{136}$. La dimensión catártica es evidente: se cumple el deseo del protagonista, el único feliz de todos los hombres preñados, y experimenta en su propia carne que los cuidados vinculados a la condición maternal están justificados por el dolor sufrido durante el parto. La conjunción de ficción y sufrimiento real es propia de los ritos iniciáticos: la aparición del lagarto, el estado de simbiosis final entre "padre" e "hijo" proyectan, con tono de ridiculez y de locura, la perfecta adecuación entre el individuo y el universo ctónico en que sigue inmerso. Este cuento es excepcional en el ciclo que venimos estudiando: el héroe desea parir, cree en la posibilidad de autofecundación por absorción y es cómplice consciente y deliberado de un proceso que para sus compadres no es sino una burla ("Pues yo quisiera tomar algo a ver si me quedaba preñao"). La única forma del tema más o menos parecida a ésta es la leyenda medieval de Nerón -que también quiere conocer la experiencia del parto y expulsa efectivamente una rana $a^{137}$, de la cual sabemos que fue difundida en Europa por colecciones de exempla tan famosas y traducidas como el Alphabetum narrationum ${ }^{138}$ : no es imposible que el cuento español sea el tardío resultado de un proceso de folklorización del exemplum, probablemente divulgado oralmente por predicadores desde finales de la Edad Media; pero tampoco se puede descartar la hipótesis de que nuestra versión española sea una reliquia de un "cuento tipo" folklórico arraigado en las tradiciones populares occidentales desde antiguo y del que la leyenda de Nerón no sería más que una adaptación semi-erudita y clerical.

${ }^{136} \mathrm{Al}$ contrario de casi todos los animales que interviene en cuentos de esta clase, el lagarto no huye: se queda "entre pañales" con su "padre" que, acostado en la cama, le pregunta: " ... ¿̇́mistes tú el que le hicistes tanto daño en el culito a papá?",

${ }_{137}$ Ranas y lagartos aparecen frecuentemente asociados, tanto en el simbolismo medieval del pecado como en narraciones folklóricas.

${ }^{138}$ Cf. Zapper1, op. cit., pp. 123-125. 


\section{RITOS EQUÍvOcos}

Tres de los motivos que confieren a esta versión su unicidad y, en cierta medida, la oponen a casi toda la tradición europea analizada por Zapperi, inducen a pensar que nos encontramos ante un caso muy interesante de preservación de un sustrato narrativo arcaico, quizá revelador de la forma occidental primigenia del tema. Primero, como ya apuntamos, el hombre quiere parir y confiesa tener envidia a las paridas por los cuidados de que son objeto $^{139}$; en segundo lugar, la parte central del relato no la constituyen las peripecias preliminares destinadas a explicar la alucinación del protagonista, sino el mismo "parto", narrado con adornos miméticos casi teatrales (los gritos de dolor) ${ }^{140}$; por fin, el cuento concluye con la imagen del "padre" y del "hijo" acostados en la misma cama.

1. Ahora bien, estos tres motivos evocan con fuerza la presunta institución o costumbre de la covada que tantos comentarios y polvareda polémica viene suscitando desde hace más de tres siglos. En una enciclopedia reciente se ha así definido la covada: "the custom of the father going to bed at the birth of his child, complaining of labour pains, observing dietary restrictions or otherwise acting like a woman in confinement. In its extreme form the mother returns to her work as soon as possible after giving birth, often the same day, and waits on the father; thus the roles of the sexes are reversed"'141.

Entre las interpretaciones psicológicas de dicho fenómeno descuella la que supone "the existence of pregnancy envy on the part of males"142, teoría especialmente desarrollada por F. Boehm, E. Fromm y, sobre todo, B. Bettleheim.

${ }^{139}$ La mención de esta "envidia" refuerza la hipótesis psicológica de BetTleHeim, op. cit., y otros psicoanalistas que explican los ritos y mitos que venimos exponiendo por el esfuerzo de los hombres para hacerse iguales a las mujeres y apropiarse del poder de procreación detentado por ellas.

${ }^{140}$ La elección de un raspón de besugo como instrumento de tortura puede ser reminiscencia de una forma antigua del cuento en que se daba una auténtica preñez del héroe por un animal más o menos sobrenatural (cf. el pez del tipo 705).

${ }^{141}$ Encyclopaedia Britannica, Chicago-London, 1971, t. 6, p. 674.

142 A Dundes, op. cit., p. 1038, y bibliografía. Para Bettleheim, op. cit., pp. 133-135, la covada entraña "association sympathique" con la madre: "L'homme désire connaître le sentiment éprouvé lors de l'accouchement ou pouvoir se dire à lui même qu'il est capable d'enfanter'. Por lo tanto hay, al mismo tiempo, "dénégation des différences biologiques" y "assimilation symbolique". El sentimiento de revancha y deseo de suplantar a la mujer se 
Además se destaca la realidad de un fenómeno de transference of pains, que tiene un aspecto semipatológico ${ }^{143}$, pero también un aspecto ritual y una finalidad mágica, llegando a veces a concretarse en partos simulados por el hombre ${ }^{144}$. Esta mímesis puede tener distintos fines que no explica exclusivamente la magia simpática: aunque es demasiado totalitaria y sistemática, la teoría "'matriarcal"' de Bachofen tuvo, por lo menos, el mérito de subrayar la importancia de los antagonismos entre sistemas de descendencia agnáticos y uterinos, y de los problemas de filiación (que hoy ya no se conciben exclusivamente con un enfoque evolucionista), y varios folkloristas y antropólogos han notado que el parto fingido corresponde en muchos casos a ritos de adopción ${ }^{145} \mathrm{o}$ de integración y legitimación. En estos casos la "ficción legal" ya sirve no para afirmar el papel del padre en la generación, sino para ajustar y adaptar los distintos registros simbólicos y reales en los que se sitúan los fenómenos socio-psicológicos provocados por la aparición de un elemento nuevo, todavía extraño, y la necesidad de incluirlo, situarlo y clasificarlo en el grupo: el padre y la madre desempeñan papeles distintos y complementarios en la adecuación de los aspectos biológicos, espirituales, familiares y sociales del nacimiento ${ }^{146}$.

nota en la brutalidad con que se trata a la que ha sufrido el parto real: el papel de la covada como regulación ritualizada de la agresividad más o menos inconsciente que sienten los esposos entre sí en el momento del parto es comentada por T. REIK, "La couvade et la psychogenèse de la crainte des représailles", Le rituel. Psychanalyse des rites religieux, Paris, 1974, pp. 41-104.

${ }^{143} \mathrm{Ibid}$, , p. 57 (casos irlandeses de maridos que comparten simpáticamente los dolores de sus esposas, que cabría comparar con la leyenda de la "Novena de los Ulatas", cf. supa, nota 98).

${ }^{144}$ Ibid., pp. 55 ss. (con resumen de la teoría de Frazer y alusiones a los casos en que la covada entraña "imitación consciente de l'accouchement accomplie par le mari pour soulager sa femme": la atenuación de los dolores se hace por su transferencia a la persona del padre. Esta explicación sólo vale para los casos de "prenatal couvade").

${ }^{145}$ Los casos españoles más famosos son la adopción de Mudarra por doña Sancha y de Ramiro por doña Mayor: en el primero es evidente la simulación de parto, ya que la "madrastra" mete al "Alnado" por la manga de su camisa y lo saca por el cabezón (A. OTERo VARELA, "La adopción en la historia del derecho español", Dos estudios hitórico-jurídicos, Madrid, 1955, pp. 128-129, con bibliografía). Sobre las analogías entre la covada y ritos de esta clase, véanse L. F. NewMAN, "Some references to the couvade in literature", Folklore, 53 (1942), pp. 152-153; R. Corso, "Il rito della covata in un racconto popolare della Corsica", Miscelánea F، Krüger, Universidad Nacional de Cuyo, Mendoza, 1952-1954, t. 2, p. 359.

I46 Cf. P. G. Riviere, “The couvade: A problem reborn”, Man, 9 (1974), 
Pero en la mayoría de los casos, la "covada" no incluye parto simulado, sino tan sólo el acostarse el padre, a veces con su hijo, y recibir felicitaciones y mimos: la imagen con la que concluye el cuento de Piedrabuena recuerda ineludiblemente añejas descripciones del rito, como las de Marco Polo ${ }^{147}$ o la no tan exótica que nos proporciona respecto de Ibiza la encuesta efectuada en 1901 por el Ateneo ${ }^{148}$.

2. Costumbres de esta clase se hallan atestiguadas en Europa desde la Antigüedad, y en la Edad Media abundan textos literarios y documentales que aluden, de modo jocoso o novelesco, al motivo del "hombre parido", siendo el más famoso el episodio de Aucassin et Nicolette, relativo al estrafalario reino de Torelore ${ }^{149}$. Pero los progresos de la ciencia etnológica de los últimos decenios, al aducir testimonios sacados de muchas culturas diferentes y situar la "covada" dentro de contextos sociales y sistemas rituales peculiares y dispares, obligan hoy a los estudiosos a revisar sus conceptos y definiciones al respecto: la covada como objeto científico ya no puede tener definición tan clara y comprensiva como en la época de Frazer o Tylor. Ya sea porque se ha descubierto que no se pueden asimilar una a otra las distintas formas y subdivisiones del supuesto fenómeno (como son covada "pesada" y "ligera" 150 , prenatal y postnatal ${ }^{151}$, ritual y psicosomáti-

pp. 423-435; P. MEnget, “Temps de naître, temps de'être: la couvade”, M. Izard y P. Smith (eds.), La fonction symbolique. Essais d'anthropologie, Paris, 1979, pp. 245-264, que insisten en el papel desempeñado por la covada en el proceso de constitución progresiva del niño como individuo completo, integrado y autónomo.

${ }^{147}$ L. F. Newman, op. cit., pp. 150-151.

148 "Tan pronto como se presenta el parto, el marido se mete en la cama con su mujer, tomando tazas de caldo como ella y colocando al recién nacido entre los dos", C. Alarco von Perfall, "El matriarcado y la discusión sobre la covada", en Cultura y personalidad en Ibiza, Madrid, 1981, p. 198.

149 Cf. LongFors, op. cit.; G. Cohen, "Une curieuse et vieille coutume folklorique, la couvade", BAB, 35 (1949), pp. 203 ss.; y Stm, 17 (1951), pp. 114 ss., que enumeran una serie de testimonios de los que conviene añadir el conocido refrán mencionado en la Comédie des proverbes de Montluc: "Servez Godard, sa femme est en couches". La leyenda escrita, la oseta y la irlandesa, mencionadas más arriba han sido relacionadas con la covada por J. VENDRYES, "La couvade chez les Scythes", CRAI (1934), pp. 329 ss. Una supervivencia europea es analizada por M. HASLuck, "Couvade in Albania", Man, 39 (1939).

150 C. Alarco von Perfall, op. cit., p. 196.

151 P. G. RiviERE, op. cit., p. 424. 
$\mathrm{ca}^{152}$, propia y figurada ${ }^{153}$, etc.), o porque la ampliación de enfoques ha permitido demostrar que tal o cual dato ritual anteriormente considerado una forma de covada, no es en realidad más que un aspecto particular de un conjunto de hechos mucho más general ${ }^{154}$. Se tiende, por ejemplo, a subrayar que "la couvade est un système de tabous qui porte sur un ensemble social, et non une collection de règles affectant le statut d'un individu... le système de la couvade n'est pas une réalité autonome... elle est une période rituelle remarquable à l'intérieur d'une séquence d'actes et de précautions tout à fait comparables qui marquent les changements d'état biologiques..." ${ }_{155}$ Pero esta aparente explosión del concepto se debe en parte al carácter prematuro de un esfuerzo de generalización teórica desarrollado a partir de datos todavía dispersos y heterogéneos, y al empleo abusivo de una palabra única para designar rituales americanos, asiáticos, europeos antiguos y modernos, algunos de los cuales han sido objeto de descripciones pormenorizadas mientras que otros se conocen sólo por alusiones, cuando no a través de tópicos literarios o folklóricos. Cabe distinguir, por ejemplo, el rito europeo - en el que se da una "substitution symbolique de la mère par le père" - y "l'ensemble plus complexe et plus répandu des pratiques sudaméricaines"'156.

152 Ibid., p. 425.

${ }^{153} \mathrm{R}$. Corso, op. cit., p. 359 . El autor relaciona directamente los rituales de covada con mitos y cuentos de parto masculino (desde el nacimiento de Atenea hasta el cuento popular corso).

${ }^{154}$ Siguiendo a A. Van Gennep, C. Levi-Straus apuntaba en una comunicación personal a g. COHEN, op. cit., p. 211: “tant de cas ont été décrits, consistant en coutumes si diverses, et se situant dans des contextes culturels si différents que nous ne savons plus du tout ce dont il s'agit, et même s'il existe une institution isolable et qui mérite un nom particulier", y citaba a Kroeber: "The couvade is not a definable recurrent phenomenon but a variable or series of intergrading phenomena", cf. RivieRE, op. cit., p. 427.

155 P. MENGET, op. cit., pp. 247-248. El autor compara la covada con la prohibición del incesto; P. G. Riviere la comparaba con el "compadrazgo" y R. Corso, con los ritos iniciáticos. En los tres casos el fenómeno tiende a difuminarse. Sin embargo nadie se resigna a negar su existencia ni a renunciar al término que lo designa, así que parece escapar al cementerio de los fantasmas epistemológicos donde yacen el "totemismo" y el "histerismo".

156 P. MENGET, op. cit., pp. 246-247, nota también que el "rito europeo" entraña una "breve imitación du rôle de la mère par le père". Ya insistía A. E. GRAWLEY, The mystic rose, London, 1902, pp. 424-425, en que "in real couvade the husband lies-in: The simulation by the father of the mother's part is obviously the essence of the custom". 
3. Quizá tan complejo como el de la definición y las interpretaciones del hecho es el problema de su implantación española, por cierto antigua y privilegiada, si cabe dar crédito a testimonios tan diversos como los de Estrabón, los de algunos viajeros más modernos por las regiones pirenáica y cantábrica, y los de la ya mentada encuesta del Ateneo, que aduce ejemplos provenientes de León, Baleares, Canarias, etc. ${ }^{157}$ Muchos de estos testimonios son sospechosos por no corresponder a observaciones directas, sino a relaciones referentes más bien a reminiscencias de un pasado más o menos remoto o a alusiones a unas costumbres supuestamente practicadas por los habitantes de regiones vecinas ("Aquí no, pero allí en la montaña..."). También se clasifican como "covada" hechos que parecen tener con ella alguna analogía, como el que el padre se ocupe de la criatura mientras que la madre se dedica a otros quehaceres, o la presentación pública del recién nacido por parte del genitor (que a veces es objeto de una "felicitación fálica"). Es de destacar que la idea de un intercambio de funciones sexuales, al suponer una feminización transitoria del hombre, provoca con frecuencia violentas y "machistas" reacciones de rechazo que se enlazan de vez en cuando con susceptibilidades regionalistas ${ }^{158}$, y que en muchos casos la "covada" corresponde, más que a una realidad social, a un sistema de representación imaginaria de los propios orígenes o de ridiculización de los "otros" - generalmente vecinos a los que se considera atrasados-, llegando a simbolizar en ambos casos el estado de barbarie del que afortunadamente se ha salido para alcanzar el actual y definitivo nivel de "civilización" 159 .

Resulta significativa, en efecto, la relación entre las ficciones narrativas a las que nos referimos en las primeras partes de este trabajo, y los pretendidos "testimonios" sobre la covada hispánica. No es casualidad si la "covada" evoca la imagen de la gallina clueca, cuya incidencia en el floklore de los "tontos" hemos examinado ya. La comparación nos permite ahora comprender el alcance de algunas anotaciones como "Aquí [Ibiza] no han 'covado'

157 Por falta de espacio me contento con remitir a las observaciones de J. Caro Baroja, "La cuestión de la covada", Los pueblos del norte de la Península Ibérica, $3^{\text {h }}$ ed., Txertoa, San Sebastián, 1977, pp. 208 ss.; y a la bibliografía de J. Gárate, "La covada pirenaica. Patrañas y fantasías", Cuadernos de Etnología y Etnografía de Navarra, 7 (1975), 383-406. Respecto a los presentes casos ibicencos, véase C. Alarco von Perfall, op. cit., cap. 9.

${ }^{158} \mathrm{Cf}$. las polémicas respecto a la covada en el País Vasco.

${ }^{159}$ Otro tanto ocurre con los cuentos y leyendas relativos a la expulsión o exterminación de los ancianos, tema del que me ocupo en otro lugar. 
nunca los hombres, que han sido siempre muy hombres. Sólo han 'covado' las lluecas" ${ }^{160}$, y de indicaciones como la de Sánchez Pérez respecto a un pueblo de León: "cuando llega el momento del parto, el marido se mete en una especie de cesta o banasta y se pone a cacarear en cuclillas como una gallina clueca que empolla" ${ }_{161}$. También explica un nombre canario de la covada, el estado de sorrocloco "que consistía en permanecer en cama (el marido) mientras lo estuviera la parida, haciéndose atender y servir como ella"' 162 .

4. La relación no parece tan evidente en lo que toca a los cuentos de "partos" masculinos. En efecto, ninguno de los ejemplos españoles de covada aducidos (y muy pocos de los que provienen de otras áreas culturales) comporta simulacro de parto por parte del padre ${ }^{163}$. Sin embargo casi todos implican una inversión más o menos relativa de los papeles sexuales, hasta el punto de que, en Menorca, "al padre que, en vez de desplegar su actividad, se tumba a la bartola, se le aplica el mote de parterot, masculino de partera" (recién parida, en el dialecto local) ${ }^{164}$.

Por lo tanto, cabe preguntarse si no se dio a veces una contaminación o confusión entre las costumbres de covada y otros ritos, más marcadamente miméticos, quizá de origen religioso o iniciático, en los que unos hombres fingen que paren, apartando sistemáticametne a las mujeres para apoderarse mejor de su privilegio biológico y acreditar la ficción de un orden puramente masculino dotado de autonomía absoluta, capaz de reproducirse sin participación de las hembras ${ }^{165}$. Mucho han insistido antropólo-

${ }^{160}$ I. Macabich, Historia de Ibiza, Palma de Mallorca, 1966, t. 2, p. 352 (cit. por C. Alarco von Perfall, op. cit., p. 201).

${ }^{161}$ J. A. Sánchez Pérez, "La covada", Investigación y Progreso, 7 (1933), pp. 216-217 (cit. por J. Caro Baroja, op. cit., p. 226).

162 Informe reproducido por J. Caro Baroja (ibid., p. 226), que admite la equiparación con "zorro-cloco" y "zorro clueco": el zorro-cloco es "hombre que parece bobo, pero que no descuida su utilidad" (cf. Corominas, $D C E C$, s.v. zorra), al mismo tiempo que equivalente de "arrumaco". Nótese que el "zorrococo" y el "zorromoco" son bufón y bailarín de danzas santanderinas (Martín Alonso, Enciclopedia del idioma, Aguilar, Madrid, 1958), sobre los cuales lamento no tener más datos.

163 Tanto más cuanto que, en muchos casos, por ejemplo en América del Sur, "le père ne joue [pas] le rôle de la mère: il joue le rôle de l'enfant" (C. Levi-Strauss, La pensée sauvage, Plon, Paris, 1962, p. 259).

164 J. Caro Baroja, op. cit., p. 226.

165 Algunos de los estudiosos que se han interesado en la covada incluyen en dicha categoría algunos simulacros rituales de esta clase. Así hizo G. 
gos y psicólogos en el hecho de que el escenario de muerte y renacimiento que entrañan los ritos iniciáticos masculinos corresponde a la intención de hacer constar que los hombres también pueden parir: la iniciación "vise à rompre le lien entre les jeunes gens et leur mère en prétendant que l'initié est remis au monde par des représentants du sexe masculin. Cette renaissance consiste á annuler le fait que c'est la mère qui a mis l'enfant au monde'"166. Fundada en la rivalidad de los sexos, la "farsa" iniciática aparece, pues, como un desarrollo de los juegos agónicos a los que aludimos antes.

Pero hemos visto que estos juegos también tienen una función asociativa y prenupcial: por consiguiente, creo que las interpretaciones psicoanalíticas de los ritos de iniciación con simulación de parto masculino, al insistir únicamente en los aspectos conflictivos, no dan cuenta cabal de todos los aspectos involucrados. Más acertados son los estudios que no descartan las funciones compensatorias y equilibradoras de las citadas inversiones, y permiten explicar por qué, correlativamente a la adopción por el hombre de posturas femeninas, se da cierta masculinización de la mujer ${ }^{167}$.

Sería un error creer que los ritos de este tipo, que, aunque distintos de la covada, bien han podido confundirse a veces con ella o contaminarla en tal o cual de sus aspectos, quedan reservados a sociedades "primitivas" y exóticas: buena prueba de ello nos es deparada por una interesantísima descripción del "xogo do parto", farsa o juego de entretenimiento que se hacía en los fiadeïros de alguna que otra parroquia de las gallegas tierras de Pon-

CoHen, op. cit., p. 208, al integrar en su nomenclatura el capítulo de la "Vida de Teseo" de Plutarco, donde se refiere un sacrificio en que "un jeune homme, couché sur un lit, imite les cris et les mouvements d'une femme en travail'". Recordamos también que $\mathrm{R}$. Corso, op. cit., pp. 358-359, refería a un rito de covada la "antica favola sulla nascita di Minerva".

166 T. ReIK, La création de la femme. Essai sur le mythe d'Eve, Paris, 1975, p. 115. Cf. B BetTleheim, op. cit., pp. 53 y 137-161.

${ }^{167}$ Cf. el importante artículo de A. S. Meigs, "Male pregnancy and the reduction of sexual opposition in a New Guinea Highlands society", Ethno$\log y, 15$ (1976), 393-407. El autor muestra que en una sociedad donde se da una separación estricta de los sexos, las investigaciones miméticas como el parto masculino fingido desempeñan un papel de neutralización y reducción, en el nivel simbólico, de oposiciones sentidas como demasiado rígidas: "Efforts are made to reduce the distance and differences between categories in the interest of reducing the discomfort of being consigned to only one"' (p. 406). G. BATESON, La cérémonie du Naven, Paris, 1971, propone un fino análisis de la función asociativa e integradora de un ritual de travestismo examinado en todas sus dimensiones. 
tedeume. Mientras hilaban las chicas, "llevaban un haz de paja y lo echaban en el suelo para hacer de cama en donde se había de celebrar el baile final. Un hombre se mete en medio de la paja y hace de parturienta, comenzando con los “dolores", que le obligan a quejarse profundamente. Los lamentos tienen modalidades diferentes de entonación y variación de vocales. Entre los lamentos salen dichos contra los hombres por ser autores de la criatura que se avecina y no padecer dolor alguno: “"-Ai! Ai! ¡Galopíns!, a vos gústabos ben o que sei eu, pero non tendes que xemer e pasar o dolor que pasamos nos»"'. Luego llaman al "médico", con el cual se entabla un diálogo: después de haber examinado completamente a la "parturienta", declara que el parto es normal. A la "madre" le dan tazas de sopas y todo acaba con un baile ${ }^{168}$. Como en el cuento de Piedrabuena, el parto asumido (o fingido) por un hombre sirve, a pesar de lo burlesco de la pantomima, para recordar a los hombres - mediante la oposición placer sexual $v s$. dolores del parto- que el nacimiento implica trabajos; también sirve para expresar, lúdicamente, una forma relativa de antagonismo sexual, finalmente arbitrado por el médico (recuérdese el papel que desempeña en el cuento de la sustitución de orines).

\section{CONCLUSIÓN}

1. Los cuentos que hemos citado contienen indudablemente un elemento burlesco, e incluso paródico, pero este elemento no parece estar esencialmente vinculado a la oposición entre "cultura folklórica" y "cultura dominante" : no se puede reducir a una crítica de los campesinos desde un punto de vista aristocráticourbano, ni a un contraataque "popular" contra los poderosos (aunque sí aparecen tendencias de ambas clases como fenómenos secundarios: el análisis de Zapperi sigue siendo valedero para muchos casos).

Las relaciones de dominación entre hombre y mujer, amos y súbditos, a veces vienen a informar conflictos preformados y rituales, y a interferir en un sistema de categorías y oposiciones propio de la cultura folklórica; pero ésta sigue manteniendo, al menos en áreas muy marcadas por las formas de vida y transmisión tradicional, sus criterios y dialéctica propios, fundados en un cons-

168 A. Fraguas Fraguas, "Literatura popular en torno al casamiento, embarazo y parto", RDTP, 32 (1976), 185-196 (pp. 195-196: información indirecta, comunicada al autor por Raúl Souto). Se trata manifiestamente de un rito arcaico transformado en xogo (Monfero, parroquia de Gestoso). 
tante reajuste de simetrías y equilibrios entre fuerzas opuestas y complementarias a la vez ${ }^{169}$. Cierto que estas fuerzas son ante todo las masculinas y las femeninas, pero las operaciones narrativas o lúdicas que las movilizan (en particular las que estriban en la representación del hombre clueco o embarazado) no tienen como finalidad la justificación de una sujeción o rebeldía, sino, como horizonte, el establecimiento -o restablecimiento- de una reciprocidad orgánica, si bien tensa, fundada en el reconocimiento mutuo de las respectivas prerrogativas y obligaciones funcionales. Siendo este sistema de intercambios considerado expresión directa de la naturaleza profunda de las cosas, no resulta extraño que su instauración, o restauración, cobre el aspecto de un acto cosmogónico, ya que hace revivir, antes de superarlo, el caos inicial, primigenio estado de locura del cual todo arranca.

2. Hemos visto que la dimensión palingenética del "loco", vector de las fuerzas anímicas que circulan por este caos, se concreta más de una vez en la imagen del hombre preñado, que hemos rastreado tanto en figuras carnavalescas como en el folklore de los "sots" medievales o de los "bobos" de la tradición oral (y teatral) hispánica.

Ahora bien, todos estos personajes son más o menos "sopladores" $\left(f_{o l}=\text { folis }=\text { fuelle }\right)^{170}$, y han heredado de sus antepasados, los "payasos rituales" que en las sociedades primitivas daban cuerpo y forma a la figura mítica del Trickster o del "Enfant Terrible", una relación privilegiada con los huevos, los excrementos y otros productos repletos de fuerza mágica ${ }^{171}$. No

${ }^{169}$ Clara burla anticlerical entraña la imagen del monje o sacerdote que lamenta no haber podido bautizar al "hijo"' que acaba de escapársele (cf. ZAPPERI, op. cit., pp. 86-87). Pero el mismo episodio puede cobrar una tonalidad patética (ibid, pp. 132-133). En la tradición folklórica se oponen las versiones en que el animal huye sin que el "padre" le pueda alcanzar (La Alberca) y las versiones que concluyen con la imagen feliz del genitor acostado, inmóvil, con su criatura (Piedrabuena). En ambos casos se puede ver una burla de la covada, pero en el primero se trata de una covada imposible o fallada, siendo el padre incapaz de retener a su progenitura; incapaz, por lo tanto, de instaurar un linaje puramente agnático.

${ }^{170}$ Cabría añadir la figura tradicional del alquimista, frecuentemente representado por la imagen del loco en su estampa postmedieval. Uno de sus propósitos es crear el homunculus, hijo nacido directamente de su padre, sin participación femenina. Recuérdese también que a los alquimistass se les solía llamar "souffleurs". Sobre el papel del fuelle en el entremés, cf. E. AsEnsio, op. cit., p. 33 (cf. la vejiga del loco del carnaval).

${ }^{171}$ Cf. Levi Makarious, op. cit.; Histoires d'enfants terribles, ed. G. CalameGriaule, Paris, 1980. 
resulta asombroso que tantas veces las ficciones de hombres embarazados desemboquen en un "parto" anal, por evacuación flatulenta o fecal, siendo reforzada la burla por previa absorción de algún potingue o por una comilona, y confundiéndose el nacimiento con la liberación intestinal del paciente.

Los psicoanalistas no han dejado de relacionar dichas ficciones con la infantil 'teoría cloacal' del nacimiento (creencia en la expulsión de las criaturas como excrementos $)^{172}$, de la que son oriundas, con toda probabilidad, las creencias arcaicas relativas al carácter benéfico del flato: gran parte del riquísimo floklore del pedo, en sus aspectos místicos (vertiente pitagórica) y burlescos (vertiente humorística de los chascarrillos pueriles y de los juegos y ritos de los "locos" o "follones" de las "compagnies joyeuses", de fines del Medioevo) estriba en la supuesta relación de la generación con una pneumatología fecundante ${ }^{173}$.

La fuerza anti-oclusiva de la crepitación anal se expresa en numerosas historias en que se ponen de relieve su carácter fausto y liberador ${ }^{174}$ o sus connotaciones propiamente "psíquicas" 175 .

172 Cf. A. Dundes, op. cit., p. 1038.

173 Motivo T 524 ("Conception from wind"). La importancia de esta "pneumatología popular" ha sido revelada y debidamente estudiada por C. GAignebet, Le folklore obscène..., cap. 1 y Le carnaval, pp. 148 ss.: "...l'Abbé de Jeunesse, la Mère Folle donne... symboliquement et analement naissance à ses confrères, aux follets, aux niais qu'il avait couvés... La parturition spirituelle est anale"' (p. 150), lo que implica previa absorción de alimentos germinativos que, desde la pitagórica faba hasta la "crèpe", equivalente carnavalesco de la hostia, hinchan real o simbólicamente el vientre: "...habillé en femme, le maïtre de la confrérie se gavait d'aliments flatulents qui lui faisaient gonfler douloureusement le ventre"' (p. 149).

174 G. LEGMan, op. cit., pp. 172 ss. ("Le pet bien inspiré"); The hornbook: Studies in erotic folklore, 1964, pp. 465-466. En la tradición oral castellana se encuentra el tema del tonto que hace reír a la princesa triste soltando un pedo (EsPINOSA, núms. 177-178, "La princesa que nunca se reía") o usando un instrumento mágico, como "la gaita (o flauta) que hacía a todos bailar", (núm. 153), que es una adaptación más decente del mismo tema, el cual se remonta a representaciones arcaicas relativas a la "risa ritual" y a la obscenidad mística (cf. el mito de Baubo).

$175 \mathrm{Cf}$. la anéctoda del ciclo de Yehá en que el tonto cree que su alma se escapa cuando su asno suelta pedos (cit. por M. MolHo, op. cit., p. 345); FABRE y LACROIX, op. cit., núm. 63, t. 2, pp. 359-362, notas y comentarios alrededor del cuento "Le ritor e la majordóna". En otras muchas ocasiones Yehá manifiesta su predilección por la flatulencia anal: cf. T. García Figueras, Cuentos de Yehá, 2a ed. Tetuán, 1950, p. 100, núm. 163 ("Me monto del lado que el caballo respira"'); J. Decourdemanche, Sottisier de Nasr-EddinHodja, Bruxelles, 1878, núms. 29 y 92. Además, Yehá es el prototipo del bobo que sabe hacer reír a la mujer imperturbable (ibid., núm. 147, y BASSET y 
Pero esta obstetricia anal culmina en ciertos cuentos que ya hemos tenido ocasión de mencionar, como el del avariento cadí de las Mil y una noches ${ }^{176}$, el de "Sapia Liccarda" en el Pentamerone ${ }^{177}$ o la "favola" que refiere R. Corso ${ }^{178}$. Estos partos son ilusorios o ficticios: más "auténticos", por así decirlo, son los que encontramos en Rabelais (los enanos engendrados por un flato de Pantagruel ${ }^{179}$ ) y, otra vez, en las tradiciones hispánicas. En efecto, en un cuento recogido en la comunidad de judíos hispanohablantes de Constantinopla, se habla de un par de mujeres cuyos estornudos dan vida, en el mundo subterráneo, a sendos hombres cuya apariencia física depende de la calidad del estornudo que los suscitón ${ }^{180}$. El cuento es, probablemente, tradicional: otra versión fue recogida (y adobada en su peculiar estilo) por Juan Valera, que la integró en sus Cuentos y chascarrillos andaluces, dándole el título de "La reina madre". En este relato las "madres", dan vida a sus respectivos y desiguales hijos soltando, la primera, un pedo inopinado y retumbante (que le permitirá granjearse las riquezas y favores del mundo subterráneo, capitaneado por el próspero hijo nacido de su flatulencia), y la segunda, un intencional aunque "lánguido, tiplado y miserable" sonido, que no producirá sino "una criatura feísima, encanijada, diminuta y enfermiza”, que no le acarreará más que disgustos a su envidiosa progenitora $^{181}$.

Aunque no se trata aquí de parto masculino, resulta evidente

Moulieras, op. cit., núm 53) y que cree en la ubicuidad del poder genético (ya que piensa o finge pensar que las ollas paren, ibid., núm. 16).

176 ZAPPERI, op. cit., pp. 217 ss. (R. F. BURTON, Supplemental nights, Benares, 1887 , t. 4 , pp. 169-185, "The story of the kazi who bore a babe").

177 G. Baslle, Pentamerone, III-4 (cf. supra, n. 32). Motivo J. 2321-2 ("Man

thinks that he has given birth to a child by letting wind"').

${ }^{178}$ Cf. R. Corso, op. cit., p. 360; el texto de la "fola" corsa se encuentra en D. CARlottr, Racconti e leggende di Cirnubella, Livorno, 1930, pp. 173-178, "Sialella": el "mago antropófago"' cree haber parido al soltar un pedo: "in c'una peta aghiu fattu una figliola!"). La "fola" se sitúa a medio camino entre el mito del nacimiento de Atenea y el cuento de Basile. Apunta el gran folklorista italiano que en Córcega se documentó la covada desde la Antigüedad, y pondera "la sua persistenza, dopo millenni, nella tradizione popolare mediterránea, sotto la forma di leggenda o di racconto" (p. 363).

179 Cf. M Bakhtine, op. cit., p. 343.

${ }^{180}$ M. L. WAGNER, Beitrage zur Kenntnis des judespanischen von Konstantinopel, Wien, 1914, pp. 59-63, núm. 11 ("El sarnudo").

$181 \mathrm{~J}$. VAlera, Obras completas, Aguilar, Madrid, 1942-1947, t. 1. pp. 1217-1220. La relación entre la versión judía y la de Juan Valera ha sido señalada por M. Vidal-Sephiha (cf. CoufFon, Histoires et légendes de l'Espagne mystérieuse, Tchou, Paris, 1968, p. 15). 
que las narraciones de esta clase han conservado, traspuesto al estilo de jocosa burla, lo que A. Dundes llama los " anal components of maie initiation": el estudio comparativo de los mitos relativos al bullroarer (o rombo) de muchas sociedades primitivas muestra que este "flatulent phallus" no es más que el instrumento destinado a simbolizar y acreditar la idea de que los iniciados renacen paridos analmente por sus iniciadores masculinos, siendo éstos los detentadores de un poder pneumático y genético - generalmente robado a las mujeres - que les permite insuflar nueva vida a los que se someten a sus ritos. ("There is...evidence supporting the notion that males attempt to supplant female procreativity through the symbolic creativity of the anus" ${ }^{182}$.) La civilización occidental moderna ya no entiende el sentido de este pretérito sistema de ideas e imágenes, pero siguió, hasta hace poco, alimentando con ellas su representación de la locura.

FRANÇOIS DELPECH

182 A. Dundes, op. cit., y sobre todo "A psychoanalytic study of the bullroarer', Man, 11 (1976), 220-238, p. 227. 